\title{
Reconstruction of Holocene oceanographic conditions in eastern Baffin Bay
}

\author{
Katrine Elnegaard Hansen ${ }^{1}$, Jacques Giraudeau ${ }^{2}$ Lukas Wacker $^{3}$, Christof Pearce ${ }^{1}$, and Marit-Solveig Seidenkrantz ${ }^{1}$ \\ ${ }^{1}$ Department of Geoscience, Arctic Research Centre and iClimate, Aarhus University, Aarhus, Denmark \\ ${ }^{2}$ Centre national de la recherche scientifique (CNRS), Université de Bordeaux, UMR 5805, Environnements et \\ Paléoenvironnements Océaniques et Continentaux (EPOC), Bordeaux, France \\ ${ }^{3}$ Laboratory of Ion Beam Physics, ETH, Zürich, Switzerland
}

Correspondence: Katrine Elnegaard Hansen (katrine.elnegaard@geo.au.dk)

Received: 18 December 2019 - Discussion started: 10 January 2020

Revised: 21 April 2020 - Accepted: 1 May 2020 - Published: 22 June 2020

\begin{abstract}
Baffin Bay is a semi-enclosed basin connecting the Arctic Ocean and the western North Atlantic, thus making out a significant pathway for heat exchange. Here we reconstruct the alternating advection of relatively warmer and saline Atlantic waters versus the incursion of colder Arctic water masses entering Baffin Bay through the multiple gateways in the Canadian Arctic Archipelago and the Nares Strait during the Holocene. We carried out benthic foraminiferal assemblage analyses, X-ray fluorescence scanning, and radiocarbon dating of a $738 \mathrm{~cm}$ long marine sediment core retrieved from eastern Baffin Bay near Upernavik, Greenland (Core AMD14-204C; $987 \mathrm{~m}$ water depth). Results reveal that eastern Baffin Bay was subjected to several oceanographic changes during the last $9.2 \mathrm{kyr}$. Waning deglacial conditions with enhanced meltwater influxes and an extensive sea-ice cover prevailed in eastern Baffin Bay from 9.2 to $7.9 \mathrm{ka}$. A transition towards bottom water amelioration is recorded at $7.9 \mathrm{ka}$ by increased advection of Atlantic water masses, encompassing the Holocene Thermal Maximum. A cold period with growing sea-ice cover at $6.7 \mathrm{ka}$ interrupts the overall warm subsurface water conditions, promoted by a weaker northward flow of Atlantic waters. The onset of the neoglaciation at ca. $2.9 \mathrm{ka}$ is marked by an abrupt transition towards a benthic fauna dominated by agglutinated species, likely in part explained by a reduction of the influx of Atlantic Water, allowing an increased influx of the cold, corrosive Baffin Bay Deep Water originating from the Arctic Ocean to enter Baffin Bay through the Nares Strait. These cold subsurface water conditions persisted throughout the
\end{abstract}

Late Holocene, only interrupted by short-lived warmings superimposed on this cooling trend.

\section{Introduction}

The opening of the Nares Strait and the narrower gateways of the Canadian Arctic Archipelago was initiated towards the end of the last glacial. It was completed in the Early Holocene at 9.3-8.3 ka when parts of the Greenland and Innuitian ice sheets, blocking these gateways, had fully retreated from the area (Jennings et al., 2019, 2011; Georgiadis et al., 2018; England et al., 2006; Zreda et al., 1999). The opening of these gateways presumably had a significant impact on the general oceanic circulation in Baffin Bay and the Labrador Sea, allowing the input of cold Arctic water masses to these regions (Jennings et al., 2019, 2017).

The modern marine environment of Baffin Bay is characterized by a combination of warm Atlantic and cold polar waters. The West Greenland Current (WGC), which flows northward along the coast of west Greenland, carries mixed, warm, Atlantic-sourced Irminger Current (IC) water and cold and fresh waters of the East Greenland Current (EGC) (Drinkwater, 1996). The onset of the present configuration of the WGC during the late glacial (Jennings et al., 2017, 2018) enabled the advection of Atlantic-sourced waters from the south along the west coast of Greenland into Baffin Bay. These waters progressively expanded from the shelf edge to shallow shelf areas during the deglaciation following the retreat of the Greenland Ice Sheet (Jennings et al., 2017; Shel- 
don et al., 2016). Today, Atlantic Water reaches the locations of Thule $\left(76^{\circ} \mathrm{N}\right)$ and the southern part of the Nares Strait at its northernmost extension off west Greenland (Buch, 1994; Funder, 1990; Knudsen et al., 2008).

Several studies suggest that eastern Baffin Bay has been subjected to a series of oceanographic and palaeoclimatic changes during the Holocene, induced by changes in the strength of the WGC linked to fluctuations in Atlantic Water entrainment and thus to changes in the Atlantic Meridional Overturning Circulation (AMOC). Most of these studies focused on the southern and central shelf regions of west Greenland (Erbs-Hansen et al., 2013; Moros et al., 2016; Lloyd et al., 2007; Perner et al., 2012; Seidenkrantz et al., 2007), but few investigated the past dynamics of the WGC in the eastern sector of Baffin Bay.

In this study, we investigate potential changes in the influx of Atlantic-sourced water to eastern Baffin Bay through the Holocene, discussing the hypothesis that changes in Baffin Bay environmental conditions are closely linked to overall changes in the Atlantic Meridional Overturning Circulation. Our study is based on micropalaeontological and geochemical investigations of a marine sediment core retrieved near Upernavik in eastern Baffin Bay. This site is located in the flow path of the WGC and in the vicinity of the marine outlet glacier Upernavik Isstrøm (Fig. 1b). Faunal assemblage analysis of benthic foraminifera, radiocarbon datings, and Xray fluorescence (XRF) data enable the reconstruction of the palaeoceanography and palaeoclimate of eastern Baffin Bay, including the temporal and spatial development of the water exchange in Baffin Bay during the Holocene.

\section{Regional setting}

Baffin Bay is a semi-enclosed basin constrained by Baffin Island to the west, Ellesmere Island to the north-west, and Greenland to the east (Fig. 1a). The basin is linked to the Atlantic Ocean via the Labrador Sea and the $640 \mathrm{~m}$ deep and $320 \mathrm{~km}$ wide Davis Strait sill in the south and is connected to the Arctic Ocean through shallow gateways: Lancaster Sound (125 m deep) and Jones Sound (190 m deep) to the north-west and the deeper Nares Strait ( $250 \mathrm{~m}$ deep) to the north (Tang et al., 2004) (Fig. 1a). The open connections between the Arctic Ocean and Labrador Sea/North Atlantic Ocean make Baffin Bay an important area for polar water export and water mass exchange with the North Atlantic Ocean (Münchow et al., 2015). The mean water depth in Baffin Bay is $<800 \mathrm{~m}$, where the deepest point of the bay in the large central abyssal region exceeds $2300 \mathrm{~m}$ water depth (Tang et al., 2004; Welford et al., 2018). The shelf region of west Greenland is incised by numerous canyons and fjords, among which Upernavik Isfjord is the nearest to our core site (Fig. 1b). The fast-flowing marine-based outlet glaciers that make up Upernavik Isstrøm terminate in the Upernavik Isfjord (Fig. 1b) (Briner et al., 2013). Previous studies suggest that retreats of these ice streams are influenced by the advec- tion of warmer Atlantic waters into the fjord (Andresen et al., 2014; Vermassen et al., 2019).

An area of maximum $80000 \mathrm{~km}^{2}$ in north-western Baffin Bay is occupied by the North Water Polynya (Dunbar and Dunbar, 1972; Tremblay et al., 2002). The prevailing northwesterly winds carry newly formed sea ice away from the polynya (Bi et al., 2019), limiting the formation of a thick sea-ice cover and resulting in open-water conditions, extensive heat loss to the atmosphere, and high marine productivity (Melling et al., 2010). The sea ice that is exported from the polynya contributes to brine formation, which may lead to the sinking of dense and cold surface waters. The sustainment of the polynya is highly dependent on strong northwesterly winds and the continuous formation of an ice bridge at Smith Sound (Fig. 1a) preventing sea ice from entering Baffin Bay through the Nares Strait (Dunbar and Dunbar, 1972; Melling et al., 2010).

The modern ocean surface circulation in Baffin Bay is driven by the local atmospheric circulation system affecting the strength of the north-westerly winds, creating an overall cyclonic ocean circulation pattern (Drinkwater, 1996) (Fig. 1a). From the south near Cape Farewell, the mixed WGC carries relatively warm saline water from the Irminger Current (IC) and cold ice-loaded polar waters from the East Greenland Current (EGC) towards the north over the shelf region of the west Greenland margin (Drinkwater, 1996; Münchow et al., 2015), creating the West Greenland Intermediate Water (Tang et al., 2004). The IC water component is mainly constrained to the continental slope in the depth range of 200-1000 m, whereas the EGC component is more shelf oriented and thus shallower (200 m), (Buch, 1994; Rykova et al., 2015). The WGC bifurcates into two branches upon reaching the Davis Strait (Cuny et al., 2002). Here, one branch flows towards the west and eventually meets and joins the Outer Labrador Current and heads south (Cuny et al., 2002; Drinkwater, 1996). The other WGC branch continues northward along the west coast of Greenland and turns westward at $75^{\circ} \mathrm{N}$, where it mixes with Arctic waters entering Baffin Bay from the north through the Nares Strait and the gateways in the Canadian Arctic Archipelago (CAA) (Drinkwater, 1996). These combined water masses make up the Baffin Current (BC), which comprises a major part of the freshwater content in the southward flowing Labrador Current (Aksenov et al., 2010; Bunker, 1976; Mertz et al., 1993; Münchow et al., 2015; Yang et al., 2016). Parts of the surface outflow from the CAA gateways recirculate eastward to eastern Baffin Bay (Canadian Coast Guard, 2012). The relative contribution of water masses from the IC and EGC plays a prominent role in the temperature and salinity signature of the WGC.

Fluctuations in the entrainment of these fresh polar water masses into the Labrador Sea have been suggested to influence the deep-water formation in the Labrador Sea and thus the Atlantic Meridional Overturning Circulation (AMOC) (Jones and Anderson, 2008; Sicre et al., 2014); consequently, 


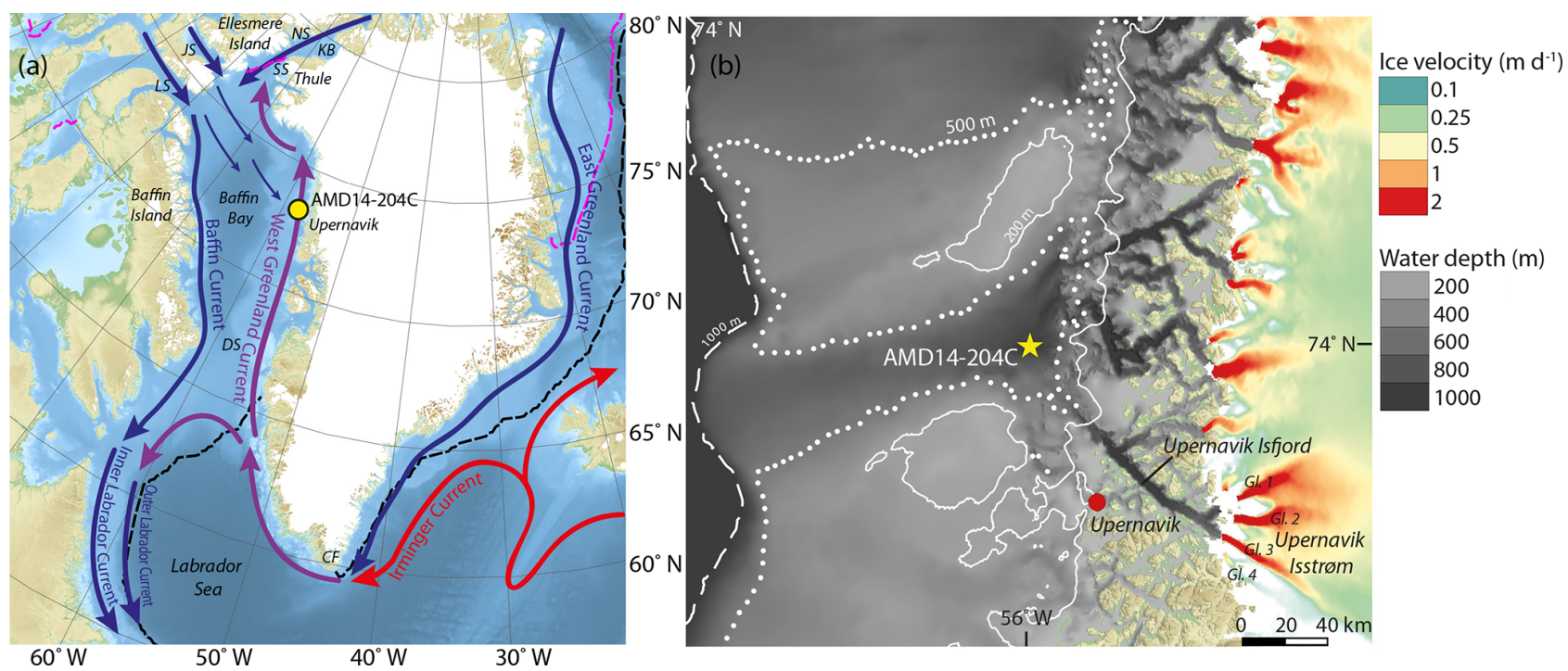

Figure 1. (a) Map showing the study site and the modern ocean surface circulation. Red, blue, and purple arrows represent warmer, colder, and mixed/intermediate water temperatures, respectively. The core AMD14-204C is marked with the yellow circle. The dashed pink and black lines mark the median sea-ice extent from 1981 to 2010 in September and March, respectively (NSIDC, 2019). Abbreviations: LS: Lancaster Sound; JS: Jones Sound; NS: Nares Strait; SS: Smith Sound; KB: Kane Basin; DS: Davis Strait; CP: Cape Farewell. (b) Close-up on the Upernavik Isstrøm area, showing the local bathymetry and ice stream velocities. The Upernavik Isstrøm is comprised of four glaciers. The ocean bathymetry and bed topography data are derived from GEBCO (Weatherall et al., 2015) and BedMachine v3 (Morlighem et al., 2017), and the ice stream velocity data are derived from Sentinel-1 SAR data acquired from 28 December 2017 to 28 February 2018 (Nagler et al., 2015). Abbreviation: Gl.: glacier.

they act as a key element in global heat transport. An increased entrainment of IC water masses into the WGC leads to increased local air temperatures and contributes to the retreat of marine outlet glaciers from west Greenland facilitated by submarine and surface melting, causing local freshening (Andresen et al., 2011; Castro de la Guardia et al., 2015; Jennings et al., 2017). Furthermore, ocean and atmospheric forced melting can contribute to a speedup of the marine outlet glaciers and general instability of the ice dynamics (Holland et al., 2008; Rignot et al., 2010; Straneo and Heimbach, 2013; Straneo et al., 2013).

The deeper part of Baffin Bay (1200-1800 m water depth) is subjected to the cold, saline Baffin Bay Deep Water (BBDW). Water masses at depths exceeding $1800 \mathrm{~m}$ are referred to as Baffin Bay Bottom Water (BBBW) (Tang et al., 2004) (Fig. 2). Several hypotheses for the source of these water masses include local brine production in connection with winter sea-ice formation on the shelf (Tan and Strain, 1980), cooled subsurface waters from Kane Basin flowing in via the Nares Strait in a pulse-like manner (e.g. Aksu, 1981; Collin, 1965), and the migration of cold, saline waters produced at the North Water Polynya (Bourke and Paquette, 1991).

The modern sea-ice duration in Baffin Bay is longest in its north-western sector, and shortest in its eastern region, influenced by the northward flow of the warmer WGC (Tang et al., 2004; Wang et al., 1994). Sea ice starts forming in open waters in the north and most of the bay is fully covered by sea ice by March (Bi et al., 2019). In September, sea ice is limited to the CAA, and Baffin Bay is primarily influenced by a sporadic thinner sea-ice cover (Tang et al., 2004) (Fig. 1a).

\section{Material and methods}

The presented multiproxy study is based on the analysis of marine sediment core AMD14-204C, a Calypso square (CASQ) gravity core collected on board the Arctic research vessel Canadian Coast Guard Ship (CCGS) Amundsen as part of the ArcticNet Leg $1 \mathrm{~b}$ expedition in 2014. The $738 \mathrm{~cm}$ long core was retrieved at $987 \mathrm{~m}$ water depth in eastern Baffin Bay $\left(73^{\circ} 15.663^{\prime} \mathrm{N}, 57^{\circ} 53.987^{\prime} \mathrm{W}\right)$ at the head of the Upernavik Trough near Upernavik Isstrøm (Fig. 1). Shortly after retrieval, the $738 \mathrm{~cm}$ long gravity core was subsampled into five core sections on board the research vessel using $150 \mathrm{~cm}$ long giant U-channels. These were subsequently kept in cold storage.

\subsection{Chronology}

The age model for core AMD14-204C is based on 11 AMS (Accelerator Mass Spectrometry) radiocarbon dates, mainly consisting of mixed benthic foraminiferal species. One sample also contains some mixed ostracod species, and two samples encompass both benthic and planktonic foraminifera due to the scarcity of calcareous material in the core (see Table 1). Four of these mixed-species radiocarbon dates have 


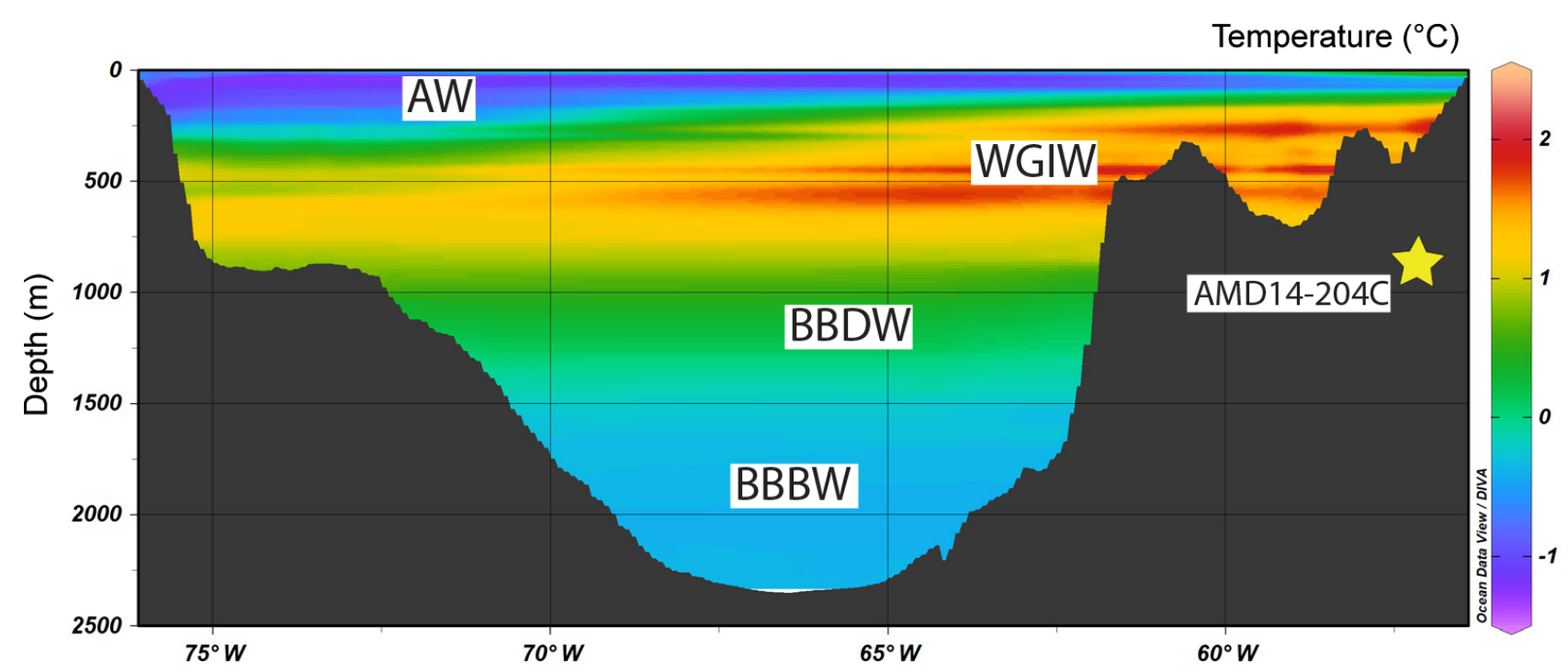

Figure 2. Water temperature transect at $73^{\circ} \mathrm{N}$ showing the different water masses. The yellow star indicates the core site at $987 \mathrm{~m}$ water depth. Abbreviations: AW: Arctic Water (0-300 m); WGIW: West Greenland Intermediate Water (300-800 m); BBDW: Baffin Bay Deep Water (1200-1800 m); BBBW: Baffin Bay Bottom Water (1200-1800 m) (Tang et al., 2004). Temperature data from World Ocean Atlas (Locarnini et al., 2013).

Table 1. List of radiocarbon dates and modelled ages in core AMD14-204C. The dates with a * sign have previously been published in Caron et al. (2018). All dates were calibrated using the Marine13 calibration curve (Reimer et al., 2013) and $\Delta R=140 \pm 30$ years.

\begin{tabular}{|c|c|c|c|c|c|}
\hline $\begin{array}{l}\text { Sample depth } \\
\text { midpoint }(\mathrm{cm})\end{array}$ & Lab. ID & Material & $\begin{array}{l}{ }^{14} \mathrm{C} \text { age } \\
(\mathrm{yr} \mathrm{BP})\end{array}$ & $\begin{array}{r}\text { Calibrated age range } \\
(\mathrm{yr} \text { cal BP }), 1 \sigma\end{array}$ & $\begin{array}{r}\text { Modelled median } \\
\text { age (yr cal BP) }\end{array}$ \\
\hline 4.5 & ETH-92277 & Mixed benthic foraminifera & $705 \pm 50$ & $167-276$ & 213 \\
\hline 70.5 & ETH-92278 & Mixed planktonic foraminifera & $1710 \pm 50$ & $1032-1175$ & 1101 \\
\hline $170^{*}$ & SacA 46004 & Mixed benthic \& planktonic foraminifera & $3555 \pm 35$ & $3139-3260$ & 3192 \\
\hline $250.5^{*}$ & BETA 467785 & Mixed benthic \& planktonic foraminifera & $4300 \pm 30$ & $4133-4254$ & 4199 \\
\hline 410.5 & ETH-92283 & Mixed benthic foraminifera & $5805 \pm 60$ & $5905-6005$ & 5959 \\
\hline 410.5 & ETH-92282 & Mixed planktonic foraminifera & $5825 \pm 60$ & $5984-6155$ & 6063 \\
\hline $501.5^{*}$ & BETA 488641 & Mixed benthic foraminifera & $6400 \pm 30$ & $6656-6751$ & 6707 \\
\hline 580.5 & ETH-92285 & Mixed benthic foraminifera & $7155 \pm 70$ & $7430-7531$ & 7483 \\
\hline 580.5 & ETH-92284 & Mixed planktonic foraminifera & $7005 \pm 60$ & $7298-7417$ & 7356 \\
\hline
\end{tabular}

previously been used in an earlier version of the age model (Caron et al., 2018), and our revised age model includes seven additional levels of radiocarbon dates measured at the ETH Laboratory, Ion Beam Physics, in Zurich (see Table 1 and Supplement for further details on the method). These latter samples are based on either pure benthic or pure planktonic species; for four of the levels we could date both samples based on benthic and on planktonic specimens, where only the samples with benthic species were used in the age model. All conventional radiocarbon ages were calibrated using the Marine13 radiocarbon calibration curve (Reimer et al., 2013) with the OxCal v4.3 software (Ramsey, 2008). A marine reservoir correction of $\Delta R=140 \pm 30$ years has previously been used in similar studies of Baffin Bay and west Greenland areas (e.g. Lloyd et al., 2011; Perner et al., 2012; Jackson et al., 2017) and is therefore used in the calibration of the radiocarbon dates in this study. Although other studies have found variable local reservoir ages throughout the Holocene (Eirksson et al., 2000), no such data exist for our study area, and therefore the $\Delta R$ is here kept constant for the entire sedimentary sequence. 


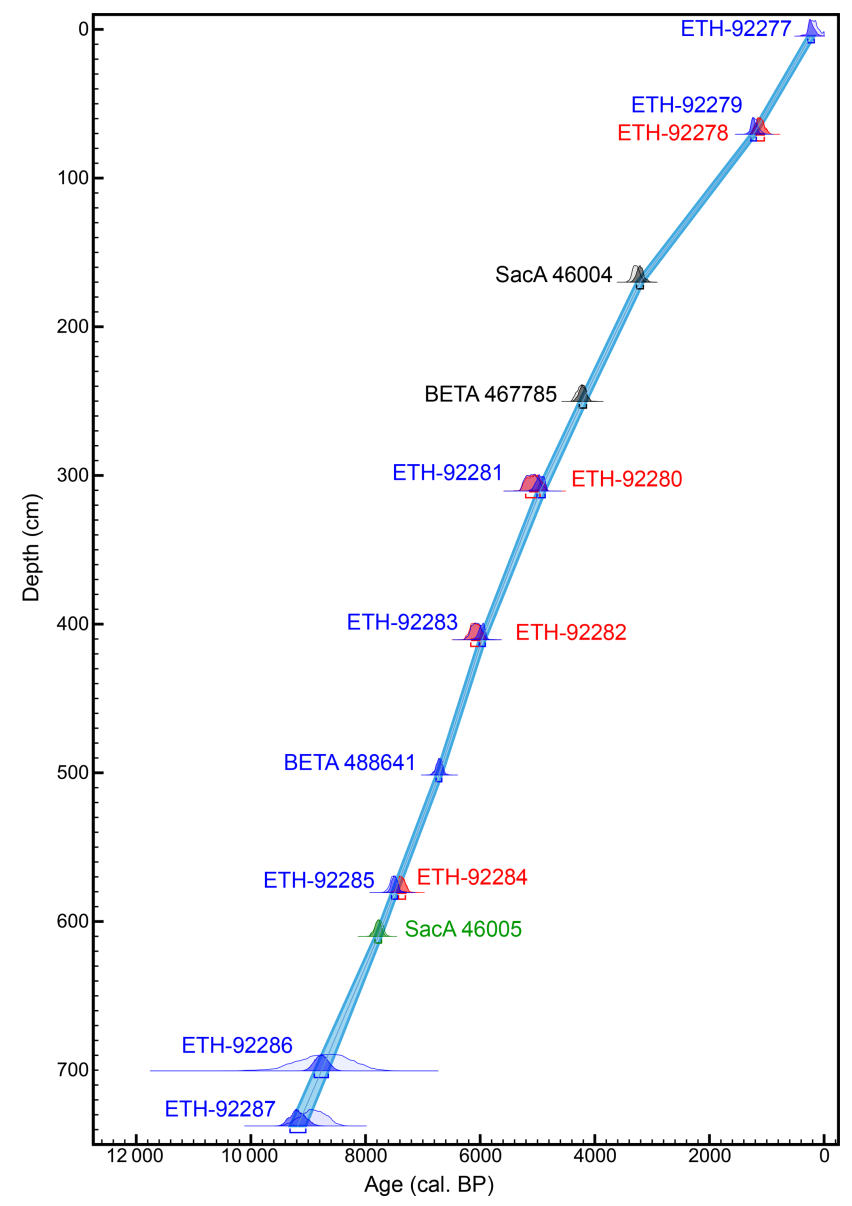

Figure 3. Age model for core AMD14-204C based on 11 radiocarbon dates (the green, black, and blue dates). The light-blue envelope represents the modelled $1 \sigma$ range, and the blue line marks the modelled median age. The light shaded areas for each radiocarbon date indicate the probability distribution prior to age modelling, whereas the darker areas indicate the posterior probability distribution. Blue: mixed benthic foraminifera; red: mixed planktonic foraminifera; grey: mixed planktonic and benthic foraminifera; green: mixed ostracods and planktonic and benthic foraminifera.

\subsection{Foraminifera}

Sediment samples of $1 \mathrm{~cm}$ width were subsampled every $10 \mathrm{~cm}$ throughout most of the core for foraminiferal analyses, except for the 500-503 cm interval, the top $(4-5 \mathrm{~cm})$, and the bottom $(737-738 \mathrm{~cm})$ of the core where every $1 \mathrm{~cm}$ was counted and subsequently used for radiocarbon dating. The wet sediment samples were weighed, followed by wet sieving using sieves with mesh sizes of $0.063,0.100$, and $1 \mathrm{~mm}$. Each fraction was dried in filter paper in the oven at $40^{\circ} \mathrm{C}$ overnight before they were weighed and stored in glass vials. For the benthic foraminiferal assemblage analyses, the 0.063 and $0.100 \mathrm{~mm}$ fractions were combined, and both calcareous and agglutinated species were identified and counted together in order to reach sufficient total counts for reliable assemblage analyses. In all cases we were able to identify at least 300 benthic individuals, following the method used in Lloyd et al. (2011) and Perner et al. $(2011,2012)$.

\subsection{X-ray fluorescence}

The non-destructive X-ray fluorescence (XRF) method allows the measurement of changes in the bulk geochemical elemental compositions of the core to be made without disturbing the sediment. The core was scanned and logged in $5 \mathrm{~mm}$ steps using an Avaatech scanner at the EPOC laboratory in Bordeaux, France. The scan was conducted with generator settings of 10,30 , and $50 \mathrm{kV}$ using a rhodium $(\mathrm{Rh})$ tube in order to get the full elemental spectra from $\mathrm{Al}$ to $\mathrm{Ba}$. Data have previously been presented by Giraudeau et al. (2020).

\section{Results}

\subsection{Core description}

The core primarily consists of hemipelagic mud. The lowermost part of the core $(610-738 \mathrm{~cm})$ is composed of greyish brown $(2.5 \mathrm{Y} 4 / 2)$ homogenous clayey silt, transitioning to bioturbated, olive grey ( 5 Y 4/2) clayey silt in the upper part of the core (Caron et al., 2018).

\subsection{Chronology}

In previous studies of Core AMD14-204C (Caron et al., 2018; Giraudeau et al., 2020), age models were based on radiocarbon dating of bulk sediment samples and palaeomagnetic markers with only a few foraminiferal ${ }^{14} \mathrm{C}$ dates. Our present study includes several new radiocarbon dates on foraminifera and therefore no longer includes the bulk datings. Our 11 calibrated ${ }^{14} \mathrm{C}$ dates, primarily based on foraminifera, reveal that the $738 \mathrm{~cm}$ long sediment core encompasses the last ca. $9200 \mathrm{kyr}$, covering most of the Holocene (Fig. 3). For the age depth modelling, a depositional $P \_$sequence model was used with a $k$ value of 0.68 (Ramsey, 2008). The average sedimentation rate for the core is $86 \mathrm{~cm} \mathrm{kyr}^{-1}$.

Pairs of mixed benthic and mixed planktonic calibrated ${ }^{14} \mathrm{C}$ dates measured at the same sample depths $-70.5,310.5$, 410.5 , and $580.5 \mathrm{~cm}$ - show only small differences (Fig. 3), all of which lie within the same age uncertainty. These results suggest that the radiocarbon ages measured from samples of mixed benthic and planktonic species are reliable. Today, the water carried by the WGC occupies the whole water column over the continental margin of eastern Baffin Bay (Cuny et al., 2002; Tang et al., 2004). The similar dates obtained from pairs of planktonic and benthic foraminiferal specimens in samples from the top to the bottom part of the core suggest that, at our study site, the subsurface and bottom waters were subjected to the same water mass throughout the Holocene with strong mixing of the water column. 


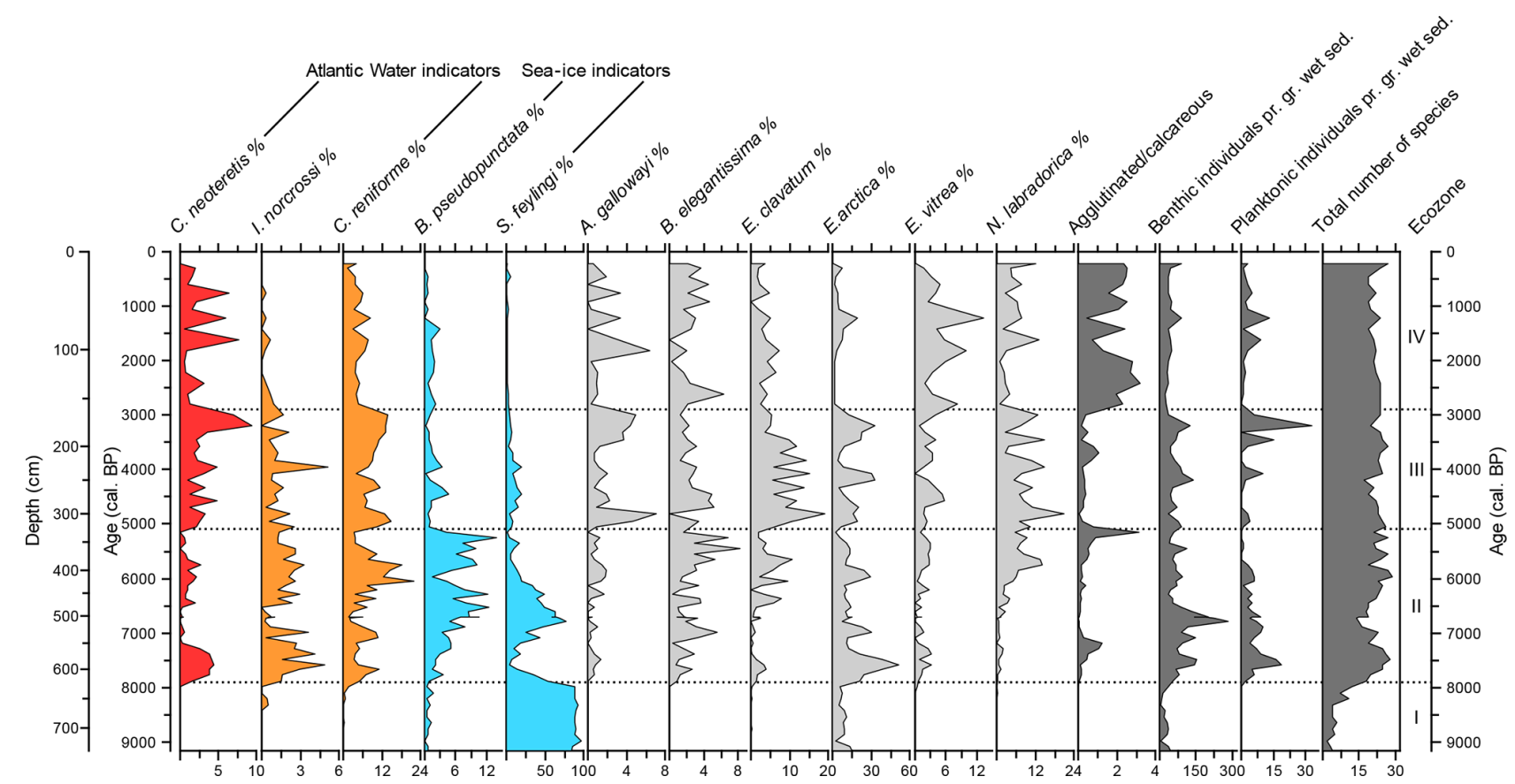

Figure 4. Downcore distribution of the most abundant ( $>4 \%$ in at least one sample) calcareous benthic foraminiferal species. Ecozones (I to IV) are shown on the right side of the figure. Relative abundances are calculated based on the entire benthic (calcareous and agglutinated) foraminiferal assemblage. Some species are grouped (colour shading) according to their known environmental preferences (see references in text) as follows: red: warm Atlantic Water; orange: chilled Atlantic Water; light blue: sea ice.

\subsection{Foraminifera}

The agglutinated and calcareous benthic foraminiferal tests were, in general, well preserved throughout the core, and there were minor signs or no signs of post-mortem dissolution of the tests. A total of 43 calcareous and 17 agglutinated benthic foraminiferal taxa were identified. The relative abundances in percent were calculated from the entire benthic foraminiferal assemblage (combined agglutinated and calcareous foraminiferal specimen assemblages to allow statistically sufficient count numbers), and the benthic species shown in the figures all have a percentage frequency of $4 \%$ in at least one of the sample intervals of the core (Figs. 4 and 5). Planktonic foraminiferal specimens are on average 10 times less abundant than benthic specimens with the lowest abundance at the bottom of the core. A downcore succession of four ecozones was defined by the visual interpretation of the species abundances, and boundaries were placed where major changes occurred in the relative abundance of the most abundant benthic species, indicative of changes in the environment.

\subsubsection{Ecozone I: 9.2-7.9 ka cal BP}

This ecozone is highly dominated by the species Stainforthia feylingi, which contributes to almost $100 \%$ of the benthic foraminiferal fauna. Only a few other species are represented here with abundances so low that they are considered insignificant. The foraminiferal concentrations are the lowest of the entire record, and planktonic specimens, as well as agglutinated benthics, are absent.

\subsubsection{Ecozone II: 7.9-5.1 ka cal BP}

The base of this ecozone is defined by a sudden increase in benthic species diversity and in both benthic and planktonic foraminiferal abundances. The abundance of $S$. feylingi decreases. Instead, Cassidulina neoteretis, Cassidulina reniforme, and Islandiella norcrossi show high abundances centred around $7.4 \mathrm{ka}$ and again at $6 \mathrm{ka}$, separated by a very low abundance at $6.7 \mathrm{ka}$, coinciding with a general low species diversity, a temporary increase in $S$. feylingi, and the common occurrence of Bolivinellina pseudopunctata. These latter two species combined constitute $70 \%$ of the fauna at $6.7 \mathrm{ka}$. Overall the abundances of the two species groups made of S. feylingi and B. pseudopunctata, on the one hand, and $C$. neoteretis, $C$. reniforme, and $I$. norcrossi, on the other hand, seem to be anti-correlated. Also noticeable is the significant abundance of up to $50 \%$ of Epistominella arctica in the beginning of the ecozone. Characteristic for the end of the ecozone is the large relative abundance of the agglutinated species compared to the calcareous benthic fauna, again coinciding with a peak abundance of $B$. pseudopunctata and a drop in frequencies of $C$. neoteretis, C. reniforme, and I. norcrossi. The most abundant agglutinated species are Porta- 


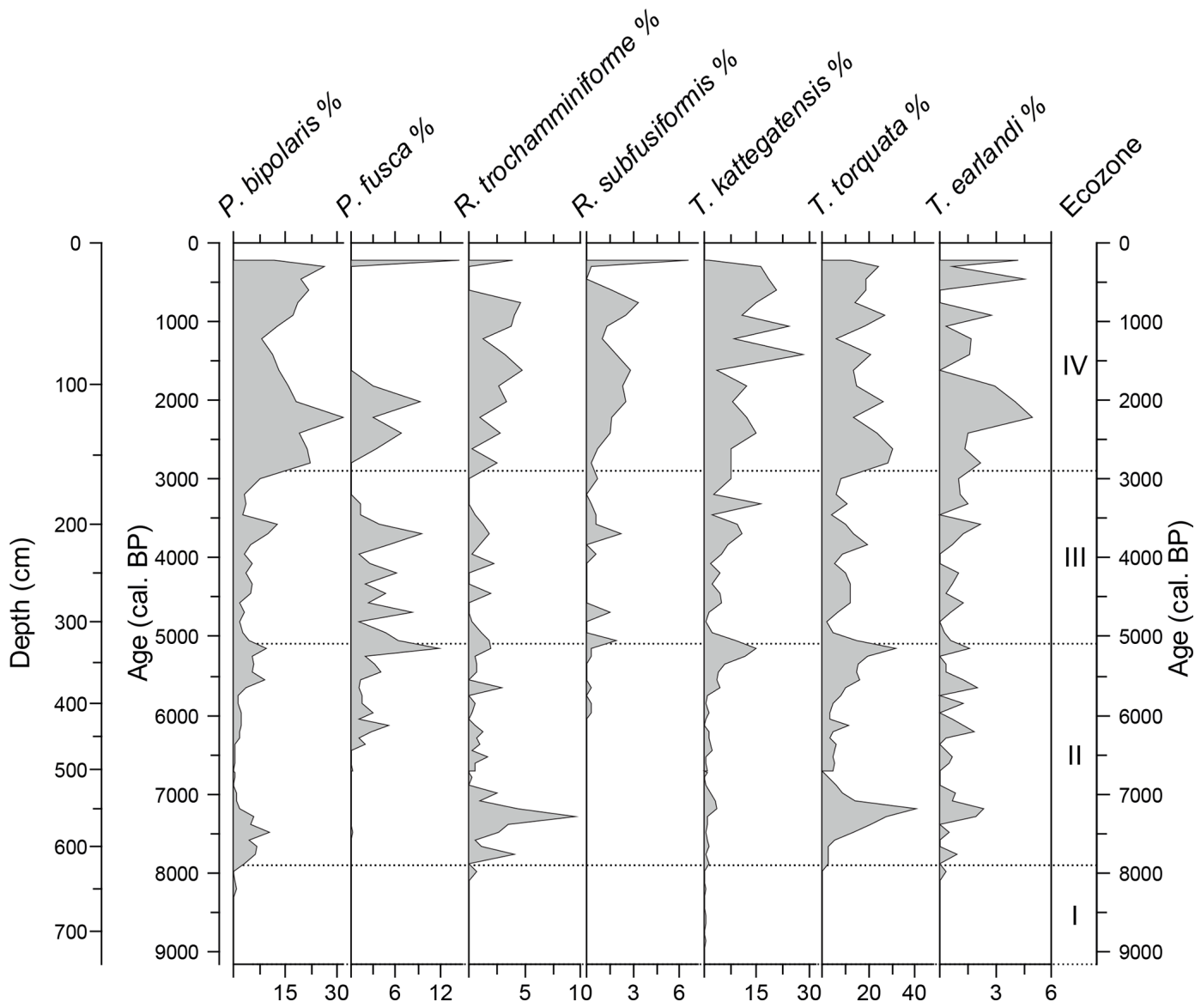

Figure 5. Downcore distribution of the most abundant (> 4\% in at least one sample) agglutinated benthic foraminiferal species. Ecozones (I to IV) are given on the right side of the figure. Relative abundances are calculated based on the entire benthic (calcareous and agglutinated) foraminiferal assemblage.

trochammina bipolaris, Recurvoides trochamminiforme, and Textularia torquata.

\subsubsection{Ecozone III: 5.1-2.9 ka cal BP}

Overall, this ecozone is characterized by fluctuating abundances of many species. Both Elphidium clavatum and Nonionellina labradorica show higher but fluctuating abundances compared to the previous ecozone. The frequency of $E$. arctica peaks three times in this ecozone, reaching abundances of around $30 \%$. Both B. pseudopunctata and $S$. feylingi display low abundances of $<1 \%-5 \%$ and $3 \%-20 \%$, respectively, while the decrease in $B$. pseudopunctata is very sudden in the beginning of the ecozone. C. neoteretis, C. reniforme, and I. norcrossi show a combined abundance of $8 \%-23 \%$. The relative frequencies of Astrononion gallowayi and Buliminella elegantissima tend to be anti-correlated, with peak abundances of A. gallowayi in the beginning $(7 \%)$ and end $(5 \%)$ of the ecozone corresponding to low $(0 \%$ and $1 \%$, respectively) contributions of $B$. elegantissima. The highest abundances of planktonic foraminifera for the entire core occur in this ecozone at $3.2 \mathrm{ka}$. The abundance of agglutinated species is, in general, low, but the frequency of Psammosphaera fusca is relatively high together with Textularia kattegatensis and T. torquata.

\subsubsection{Ecozone IV: 2.9-0.2 ka cal BP}

This ecozone is characterized by a sudden increase in the agglutinated / calcareous benthic species ratio, as the agglutinated specimens outnumber the benthic calcareous individuals by a factor of 3. P. bipolaris, T. kattegatensis, and $T$. torquata are among the most abundant agglutinated species in this ecozone. The dominance of agglutinated species coincides with a drop in the contributions of planktonic foraminifera, as well as of the benthic species $C$. neoteretis, C. reniforme, and I. norcrossi. The high abundances of agglutinated species persist towards the top of the core and are only interrupted by three periods of lower values at 1.6, 1.2, and $0.8 \mathrm{ka}$, which correspond to intervals with a high contribution of $C$. neoteretis $(6 \%-8 \%)$ and $C$. reniforme $(6 \%-8 \%)$. I. norcrossi is, in general, poorly repre- 
sented in this ecozone $(<1 \%)$, while the percentage frequency of $C$. reniforme is generally stable but lower than in ecozones II and III. Epistominella vitrea experiences its highest mean relative abundance of the entire core within Ecozone IV, peaking at $1.2 \mathrm{ka}(13 \%)$. E. clavatum, E. arctica, and $N$. labradorica abundances decrease compared to the preceding ecozone, and both S. feylingi and B. pseudopunctata are poorly represented in this ecozone.

\subsection{Geochemistry}

The XRF record shows several smaller events in addition to a general downcore pattern (Fig. 6). Giraudeau et al. (2020) interpreted the elemental composition of this core in relation to the provenance of source sediments. Here we primarily focus on the terrestrial versus marine signal. Ecozone I is characterized by relatively low values of $\mathrm{Br}$ and $\mathrm{Ca} / \mathrm{Ti}$ while the $\mathrm{K}$ and $\mathrm{Rb}$ counts are high. Counts of $\mathrm{Br}$ increase throughout ecozones II-III and become more or less stable in Ecozone IV. The opposite pattern characterize the $\mathrm{K}$ and $\mathrm{Rb}$ counts. Both the $\mathrm{Ca} / \mathrm{Sr}$ and $\mathrm{Ca} / \mathrm{Ti}$ ratios are relatively stable throughout the core, although a slight increasing trend is seen in the $\mathrm{Ca} / \mathrm{Ti}$ ratio towards Ecozone IV. Both ratios show a prominent peak at around $6.7 \mathrm{ka}$ in Ecozone II, coinciding with the highest values of ice-rafted debris (IRD) concentrations in the core.

We consider the element $\mathrm{Br}$ as an indicator of marine biological productivity often associated with high amounts of marine organic matter (Pruysers et al., 1991). High counts of this element therefore indicate a minimal contribution of terrestrial-sourced material to the bulk sediment (Calvert and Pedersen, 1993; Rothwell and Croudace, 2015). K and Rb are both typical for environments with terrestrial influence (Saito, 1998; Steenfelt, 2001; Steenfelt at al., 1998). The $\mathrm{Ca} / \mathrm{Ti}$ and $\mathrm{Ca} / \mathrm{Sr}$ ratios can be used as indicators of the marine biogenic origin of $\mathrm{Ca}$ (Bahr et al., 2005; Richter et al., 2005). IRD counts and the mean grain size record are both indicators of terrestrial influence, since larger grain sizes can be related to iceberg calving and/or increased sediment delivery by the Upernavik Isstrøm. More information about these two records is available in Caron et al. (2018) and Giraudeau et al. (2020).

\section{Palaeoenvironmental interpretation}

The distributional patterns of foraminiferal assemblages are indicators of changes in bottom and subsurface water conditions. Changes in the abundance ratio of agglutinated versus calcareous specimens in sediments of Baffin Bay are often interpreted as evidence of subsurface deterioration, occasionally linked to the influx of the cold, saline, and corrosive $\mathrm{CO}_{2}$-rich Baffin Bay Deep Water (BBDW) (Jennings, 1993; Jennings and Helgadottir, 1994; Knudsen et al., 2008; Schröder-Adams and Van Rooyen, 2011). Off west Greenland, I. norcrossi and C. neoteretis are generally considered indicators of increased advection of Atlantic IC water into the WGC based on their preference of relatively warm and highsalinity waters (Knudsen et al., 2008; Perner et al., 2012; Seidenkrantz, 1995; Lloyd, 2006), albeit with I. norcrossi likely tolerating colder conditions and increased mixing with polar water compared to C. neoteretis. C. reniforme has also been used as an indicator species for chilled Atlantic Water, although it can live in somewhat colder water masses than the other Atlantic Water indicator species presented here (Ślubowska-Woldengen et al., 2007). High abundances of $S$. feylingi and B. pseudopunctata are often considered associated with high primary productivity in the proximity of seaice edges; both species are tolerant to reduced bottom water oxygen content (Knudsen et al., 2008; Seidenkrantz, 2013; Sheldon et al., 2016). According to Seidenkrantz (2013), $S$. feylingi can be regarded as a typical sea-ice edge indicator species. These micropalaeontological proxy data, together with geochemical (XRF core scanner-derived) and sedimentological data, allow us to infer palaeoenvironmental conditions within each period defined by the four foraminiferal ecozones.

\subsection{Ecozone l: 9.2-7.9 ka cal BP}

The total dominance of $S$. feylingi prior to $7.9 \mathrm{ka}$ implies that conditions were unfavourable for other foraminiferal species. S. feylingi is an opportunistic species, which can tolerate unstable low-oxygen conditions on the sea floor related to a stratified water column (Knudsen and Seidenkrantz, 1994; Patterson et al., 2000). The relatively high counts of the terrestrially derived elements $\mathrm{K}$ and $\mathrm{Rb}$ and a low $\mathrm{Ca} / \mathrm{Ti}$ ratio, together with relatively high sedimentation rates $\left(0.092 \mathrm{~cm} \mathrm{yr}^{-1}\right)$, could indicate an increased meltwater influence from the Greenland Ice Sheet (GIS). Furthermore, the low $\mathrm{Br}$ counts and low absolute abundance of foraminifera imply that the general marine productivity was low (Calvert and Pedersen, 1993; Pruysers et al., 1991). The absence of Atlantic Water indicator species suggests a weakening of the Atlantic Water entrainment into the WGC, possibly in connection with a WGC flow path located further away from the shelf. From 9.2 to $7.9 \mathrm{ka}$, the eastern Baffin Bay region was therefore characterized by continuous meltwater injections from the Greenland Ice Sheet and an extensive sea-ice cover associated with the final phase of the deglaciation.

\subsection{Ecozone II: 7.9-5.1 ka cal BP}

The overall increase in species diversity from $7.9 \mathrm{ka}$ indicates a transition towards ameliorated subsurface water conditions with higher marine biogenic productivity. The general decrease in $\mathrm{Rb}, \mathrm{K}$, and mean grain size and increasing $\mathrm{Br}$ values point to a smaller influence of terrestrially derived sediment, possibly related to reduced meltwater inputs from the retreating Greenland Ice Sheet. 


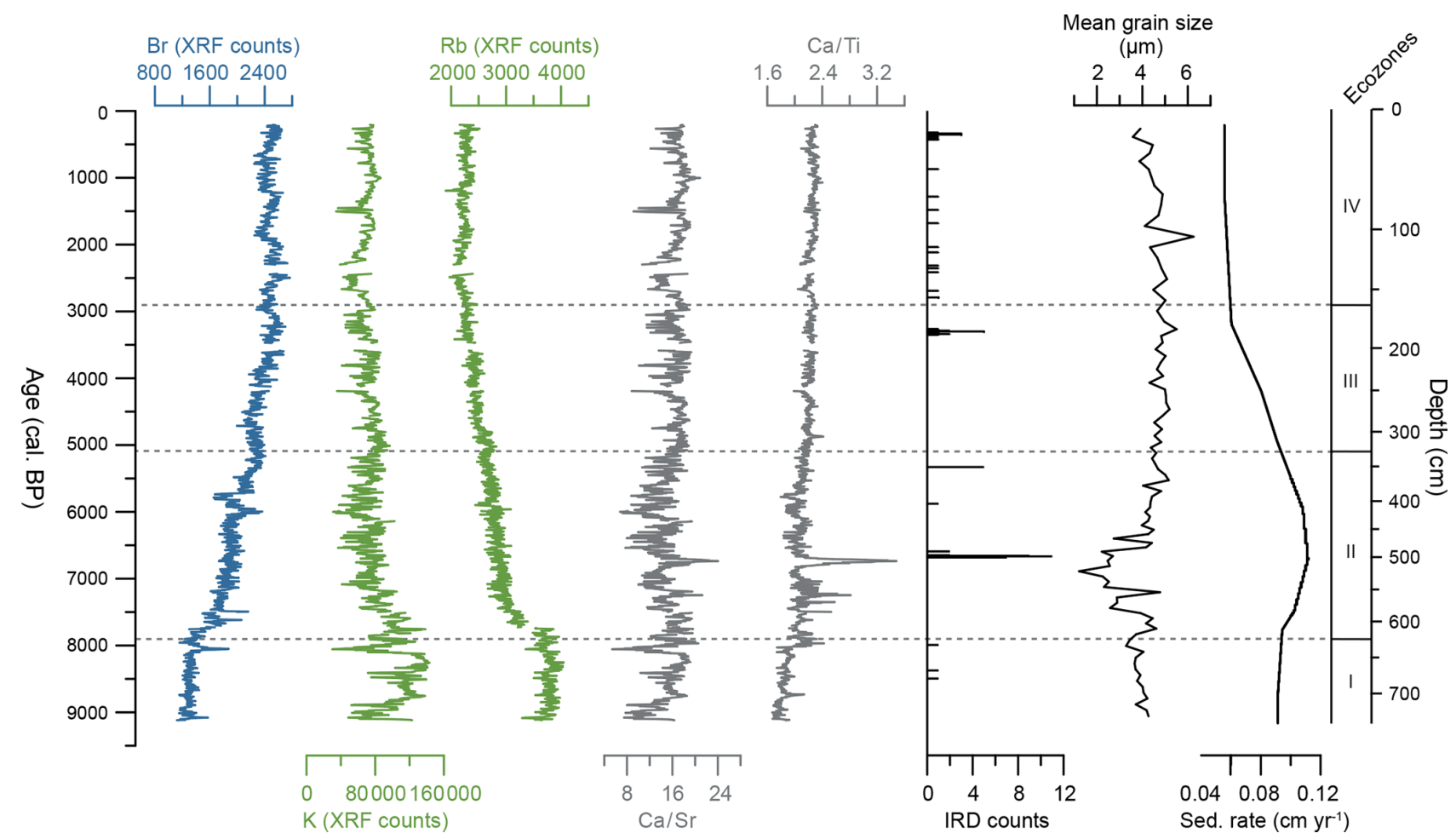

Figure 6. From left to right: X-ray fluorescence data, IRD concentration, mean grain size expressed in micrometres ( $\mu \mathrm{m})(\mathrm{Caron}$ et al., 2018), and sedimentation rate in core AMD14-204C. The benthic foraminiferal ecozones are given on the right side of the plot. Gaps in data indicate missing data.

These improved subsurface water conditions were plausibly facilitated by a stronger entrainment of Atlantic water masses into the WGC, inferred from the high contribution to the foraminiferal assemblages of Atlantic Water indicator species together with an increase in P. bipolaris, which has previously been linked to the presence of Atlantic Water in the nearby Disko Bugt (Disko Bay; Wangner et al., 2018). The Atlantic Water incursion seems especially strong at around $7.4 \mathrm{ka}$, coinciding with an increase in planktonic foraminifera, indicative of increasing air temperatures and warming of the (sub)surface waters, and further supported by the low abundances of benthic sea-ice indicator species. Particularly the low abundance of $S$. feylingi coinciding with high percentages of E. arctica point to a reduction in the seaice cover and high productivity (Seidenkrantz, 2013; Wollenburg and Mackensen, 1998).

The advection of Atlantic Water decreased significantly at $6.7 \mathrm{ka}$, as indicated by the sudden decrease in abundances of Atlantic Water indicator species and a decrease in planktonic foraminifera. An increase in benthic sea-ice indicator species and an overall low benthic foraminiferal species diversity imply that the area was subjected to colder air temperatures, associated with an expansion of the sea-ice cover and a worsening of the subsurface conditions. Additionally, the transition towards a higher abundance of benthic sea-ice species coincides with a large abundance peak of the agglutinated cold- water species T. torquata (Perner et al., 2012; Wangner et al., 2018). The peak values in the $\mathrm{Ca} / \mathrm{Ti}$ and $\mathrm{Ca} / \mathrm{Sr}$ ratios around 6.7 ka suggest that a high amount of carbonate was exported to the area, possibly deposited as ice-rafted debris (IRD) according to the synchronous high IRD counts (Fig. 6). Previous studies have described the presence of detrital carbonate in Baffin Bay, related to deposition by icebergs and/or sea ice (e.g. Andrews et al., 2011; Jackson et al., 2017). This short-lived cold period at $6.7 \mathrm{ka}$ can be related to a temporarily weaker incursion of Atlantic Water off west Greenland, enabling cold polar waters to enter Baffin Bay either in the form of increased EGC entrainment into the WGC or as polar water delivered from the Canadian Arctic Archipelago. The event may potentially designate a very late meltwater event affecting the ocean circulation, but further investigations are needed to test this hypothesis.

At ca. $6.0 \mathrm{ka}$, the Atlantic Water contribution to WGC again increased while sea ice retreated, based on the high frequency of the Atlantic Water indicator species and the low abundance of sea-ice indicator species. The prevailing conditions were similar to those around $7.4 \mathrm{ka}$, but the lower abundance of the true Atlantic Water indicator species C. neoteretis (cf. Seidenkrantz, 1995) implies that subsurface conditions were not as warm as around $7.4 \mathrm{ka}$.

The high agglutinated / calcareous foraminiferal ratio coinciding with low abundance of the Atlantic Water indica- 
tor species just prior to $5.1 \mathrm{ka}$ implies a short period of cold and corrosive subsurface waters, unfavourable for most of the calcareous benthic species. However, these conditions were favourable for the opportunistic benthic species B. pseudopunctata, which has been linked to environments with lowoxygen conditions (Gustafsson and Nordberg, 2001; Patterson et al., 2000). This deterioration of the subsurface water environment can possibly be attributed to the decreasing strength of the WGC together with the presumably reducing Atlantic Water entrainment and a stronger influence of the cold, corrosive BBDW.

\subsection{Ecozone III: 5.1-2.9 ka cal BP}

A general amelioration of the bottom water environment and decreasing sea-ice cover, promoted by a stronger Atlantic Water entrainment at $5.1 \mathrm{ka}$, is suggested by an increased contribution of Atlantic Water species and decreasing abundances of B. pseudopunctata and S. feylingi. High contributions of A. gallowayi and E. clavatum imply that the hydrodynamic activity on the sea floor was high and unstable in the beginning and end of the ecozone (Knudsen et al., 1996; Korsun and Hald, 2000; Polyak et al., 2002), which is hereby related to a strengthening of the WGC flow.

The low abundances of $B$. elegantissima are possibly caused by the high turbidity levels. High salinities linked to the strong entrainment of Atlantic-derived water masses can also be inferred for this time period, considering the tolerance of A. gallowayi for raised salinity conditions (Korsun and Hald, 1998). This fits well with the synchronous higher contributions of $C$. reniforme, which previously had been associated with the incursion of chilled saline Atlantic waters (Ślubowska-Woldengen et al., 2007).

The primary productivity species $N$. labradorica is often associated with the presence of fresh phytodetritus in relation to primary productivity blooms and oceanic fronts (Jennings et al., 2004; Polyak et al., 2002; Rytter et al., 2002). At our study site, this species seems to thrive under generally warm bottom water conditions. E. arctica and E. vit$r e a$, which are also both productivity indicators (Perner et al., 2012; Scott et al., 2008; Wollenburg and Kuhnt, 2000; Wollenburg and Mackensen, 1998), show somewhat more fluctuating distributions in this ecozone, which could be linked to shifting nutrient supply and fluctuating turbidity at the bottom. The overall high abundances of benthic productivity indicators reveal improved bottom water conditions with high food availability.

\subsection{Ecozone IV: 2.9-0.2 ka cal BP}

The sudden drop in calcareous foraminiferal concentrations illustrated by the very sudden increase in the agglutinated / calcareous benthic ratio suggests that the decrease in the abundance of calcareous specimens is most likely not a result of the poor post-mortem preservation of these species within the core but rather related to environmental changes in the bottom waters. This is also supported by the fact that the calcareous specimens are well preserved after $2.9 \mathrm{ka}$. We suggest that the unfavourable conditions for the calcareous benthic foraminifera are associated with an increasing influx of BBDW, impeding test formation of the calcareous species because of the cold, corrosive property of this deep water mass. The increased inflow of BBDW was presumably promoted by an overall weaker WGC flow and a diminishing entrainment of Atlantic Water into the WGC, as inferred from the phased decrease in abundance of Atlantic Water indicator species. Additionally, the lower sedimentation rate $\left(0.056 \mathrm{~cm} \mathrm{yr}^{-1}\right)$ throughout this ecozone could possibly be yielded by a weaker WGC flow strength. However, the continued, albeit lower, presence of Atlantic Water species and well-preserved calcareous specimens indicates some continued, at least intermittent, influx of Atlantic Water.

The short-term events of increased abundances of Atlantic Water indicator species and high planktonic foraminiferal concentrations centred roughly at $1.6,1.2$, and again at $0.8 \mathrm{ka}$ are possibly linked to periods of strengthening of the Atlantic Water entrainment into the WGC, resulting in shortterm amelioration of the bottom and surface water conditions. The restrengthening of the WGC flow is supported by coinciding peak abundances of $A$. gallowayi (Polyak et al., 2002). The productivity indicator species $E$. vitrea seems to favour conditions with a relatively strong WGC possibly associated with the introduction of certain nutrients to the area. Although the overall colder bottom water conditions could be expected to induce increased sea-ice cover, conditions do not seem to have been favourable for the sea-ice indicator species $S$. feylingi and B. pseudopunctata. However, these species are particularly thin-shelled and thus highly sensitive to corrosive bottom water conditions.

\section{Discussion}

The interpretations of the benthic foraminiferal assemblage fauna and XRF data from this study suggest that several oceanographic and climatic changes occurred during the Holocene in eastern Baffin Bay, which are associated with the relative change of Atlantic Water mass advection, the influence of ice sheets, the inflowing water masses derived from the Arctic Ocean, and the extent of sea-ice cover. The changes herein are summarized in Fig. 7 with the number of planktonic foraminifera and the sea-ice indicator species representing the surface water conditions and the agglutinated / calcareous ratio representing fluctuations in deteriorating bottom water conditions related to the incursion of colder, corrosive BBDW. The grouping of the Atlantic Water foraminifera was done following the methods of Lloyd et al. (2011) and Perner et al. (2012, 2011), where C. neoteretis, C. reniforme, and I. norcrossi were grouped, to represent the alternation of Atlantic Water mass advection to eastern Baf- 


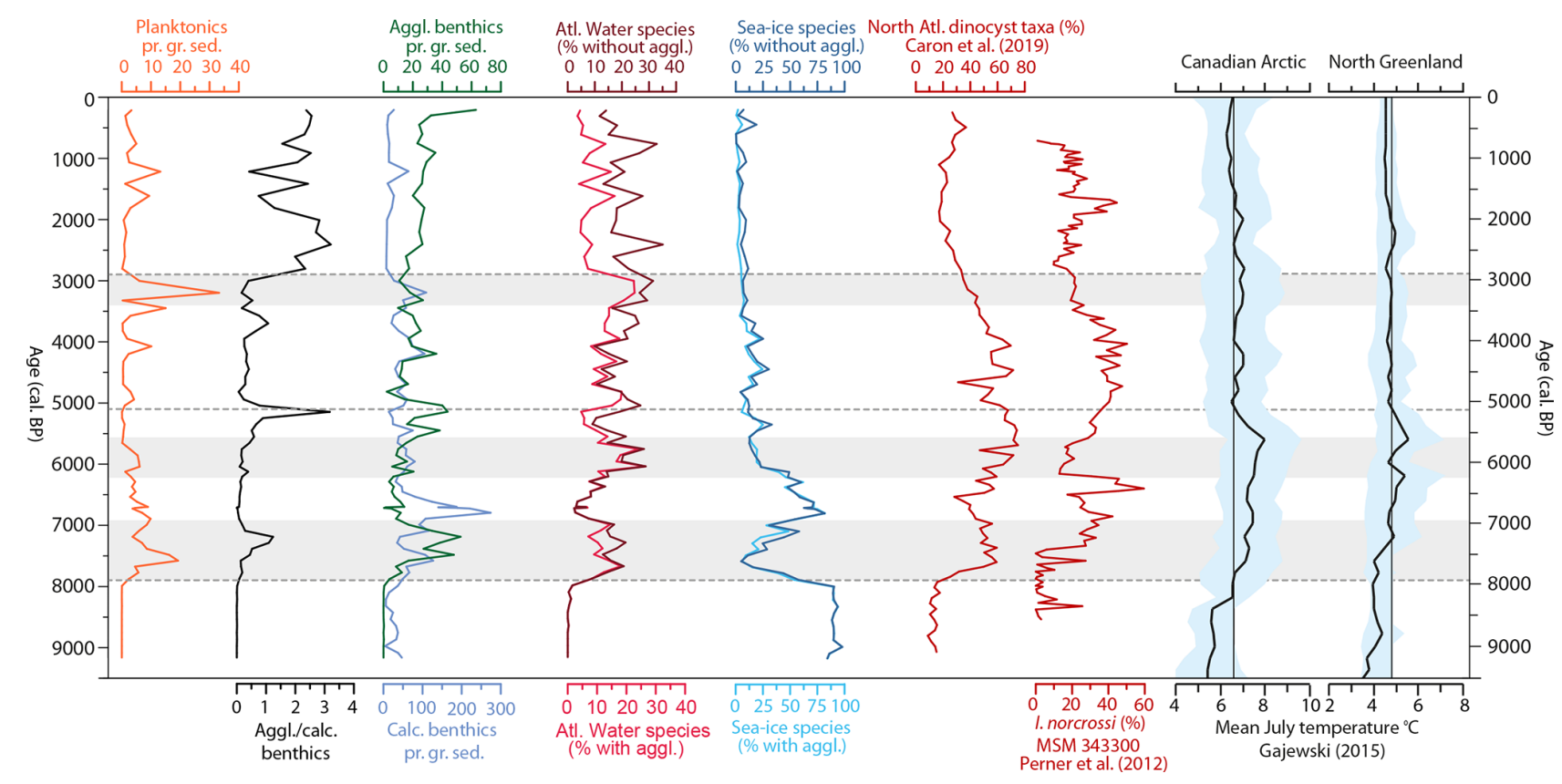

Figure 7. The green and purple curves show the comparison of the agglutinated benthics and calcareous benthics in individuals per gram of wet sediment, respectively. The sea-ice indicator species curves represent a grouping of the two sea-ice indicator species, $S$. feylingi and B. pseudopunctata, shown in percentages, including with agglutinated species (light blue) and without agglutinated species (dark blue). C. neoteretis, C. reniforme, and I. norcrossi make up the Atlantic Water indicator species shown in percentages, including with agglutinated species (light red) and without agglutinated species (dark red). The grey bars represent periods of strengthening of the WGC related to a stronger Atlantic Water entrainment. The foraminiferal data are compared to North Atlantic dinocyst taxa (Caron et al., 2019) and the Atlantic Water indicator species I. norcrossi from core MSM343300 from Disko Bugt (Perner et al., 2012). Additionally, two temperature reconstruction records are included, which show the mean regional July temperature (black line) from selected sites and were constructed by using the modern analogue technique (MAT) on pollen records from lake sediments (Gajewski, 2015). The light-blue shaded areas indicate the regional 1 standard deviation, and the straight vertical line is the long-term average of the curve.

fin Bay. The percentage distribution of the Atlantic Water group is represented by two curves. One calculated based on the combined benthic foraminiferal assemblage including both agglutinated and calcareous species and one without the agglutinated species. This was done in order to evaluate whether increases in this group are driven by lower abundances of the agglutinated species. Additionally, the species B. pseudopunctata and S. feylingi were grouped based on their preference for phytoplankton blooms related to sea-ice margins. The sea-ice species group is also represented by two different curves. In Fig. 7, the summary curves from this study are compared with the estimated mean July air temperature, derived from regional pollen data from lake cores by using the modern analogue technique (Gajewski, 2015).

\subsection{Early Holocene}

Several studies based on marine sediment cores from Baffin Bay and adjacent areas indicate that this region was subjected to cold deglacial conditions during the earliest part of the Holocene. A magnetic property study by Caron et al. (2018), carried out on core AMD14-204C, suggests that the homogeneous clayey silts found from 9.2 to $7.7 \mathrm{ka}$ and high values of
$\mathrm{MDF}_{\mathrm{NRM}}$ and magnetic susceptibility represent a deglacial deposition dominated by glacially derived material from an ice-distal environment. Median destructive field of the natural remanent magnetization, or $\mathrm{MDF}_{\mathrm{NRM}}$, is a magnetic mineralogy indicator in palaeomagnetic analyses. These results are supported by studies of lake sediments adjacent to the ice stream, which suggest that the Upernavik Isstrøm had retreated close to its modern position (Briner et al., 2013).

The strong influence of cold polar waters from the Arctic Ocean and extensive sea ice, which is suggested by the dominance of S. feylingi and the low abundance of the North Atlantic dinocyst taxa (Caron et al., 2019) (Fig. 7), corresponds to a deglacial cooling associated with the opening of the Nares Strait. This promoted enhanced advection of polar waters and variable sea-ice cover in Kane Basin in 9.0$8.1 \mathrm{ka}$, based on biomarker and foraminiferal data from core AMD14-Kane2b (Fig. 8) (Georgiadis et al., 2020).

Similar cold conditions are also observed further southwest of the AMD14-204C core site. In the Labrador Sea (core MSM45-19-2 in Fig. 8), colder conditions were observed during the period $8.9-8.7 \mathrm{ka}$, likely caused by increased advection of colder, southward-flowing Baffin Bay water masses into the Labrador Current (Lochte et al., 2019). 


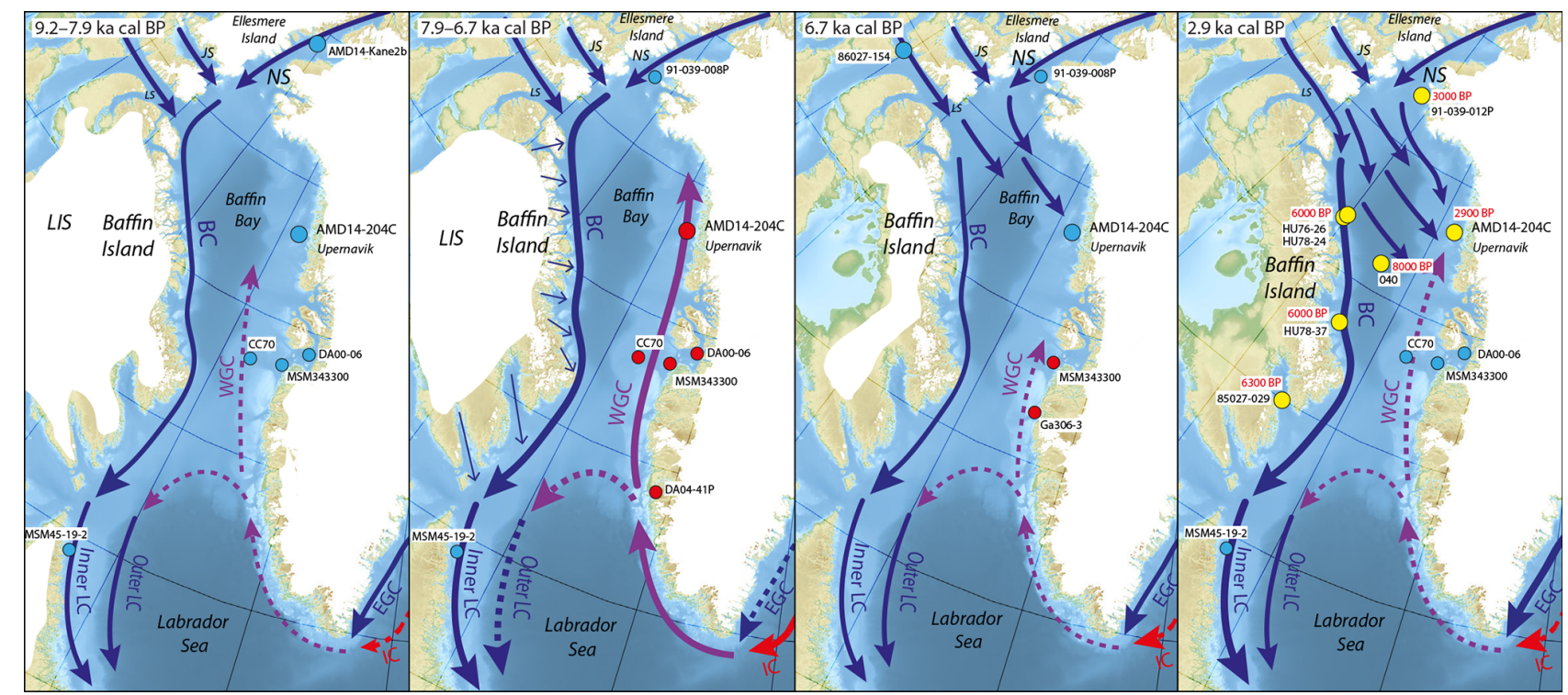

Figure 8. Map showing the oceanographic conditions in the Baffin Bay and Labrador Sea areas from 9.2 to $2.9 \mathrm{ka}$ based on this core and other cores from the area: AMD14-Kane2b (Georgiadis et al., 2020), MSM45-19-2 (Lochte et al., 2019), CC70 (Gibb et al., 2015), DA00-06 (Lloyd et al., 2005), DA04-41P (Seidenkrantz et al., 2013), MSM343300 (Perner et al., 2012; Moros et al., 2016), 91-039-008P (Levac et al., 2001), 86027-154 (Pieńkowski et al., 2014), 91-039-012P (Levac et al., 2001; Knudsen et al., 2008), HU76-26, HU78-24, HU-78-37 (Osterman and Nelson, 1989), 040 (Aksu, 1983), and 85027-029 (Jennings, 1993). Red and blue cores represent relatively warmer and colder conditions, respectively. Solid and dashed arrows indicate stronger and weaker ocean currents, respectively. The straight blue arrows at Baffin Island at 7.9-6.7 ka indicate meltwater run-off into the ocean. The yellow cores at $2.9 \mathrm{ka}$ indicate sediment cores where a change towards an agglutinate-dominated benthic fauna occurred. Red numbers indicate the timing of this transition. Reconstruction of ice-sheet extents are modified from Dyke (2004). Abbreviations: LIS: Laurentide Ice Sheet; LS: Lancaster Sound; JS: Jones Sound; NS: Nares Strait; BC: Baffin Current; LC: Labrador Current; IC: Irminger Current; EGC: East Greenland Current; WGC: West Greenland Current. The ocean bathymetry and bed topography data are derived from GEBCO (Weatherall et al., 2015).

Additionally, the benthic foraminiferal fauna indicates extreme conditions with low food supply and low-oxygen conditions related to an extensive sea-ice cover (Lochte et al., 2019) (Fig. 8). These environmental conditions are further supported by dinocyst data from eastern Baffin Bay west of Disko Bugt (core CC70), indicating cold surface water conditions and extensive sea-ice cover prior to $9.5 \mathrm{ka}$ (Gibb et al., 2015). These data also show a shift towards slightly higher salinities and reduced sea ice at $\sim 9.5 \mathrm{ka}$, suggesting a decreasing influence of proximal ablation from the GIS (Gibb et al., 2015).

The Disko Bugt in central west Greenland was subjected to similar cold conditions, where sedimentological and benthic foraminiferal data from a marine sediment core near the Jakobshavn Isbræ (core DA00-06) imply that the WGC influence was weaker and highly influenced by significant meltwater influxes already prior to $8.3 \mathrm{ka}$ (Lloyd et al., 2005). Additionally, a second study from the Disko Bugt area (core MSM343300) documents high abundances of Arctic benthic foraminifera, proposing a subsurface water cooling coinciding with increased meltwater injection and sea-ice supply to the surface water, which is inferred from dinocyst, diatom, and alkenone (\% $\left.\mathrm{C}_{37: 4}\right)$ data (Moros et al., 2016) (Fig. 8).
Accordingly, it seems that both surface and subsurface water conditions in eastern Baffin Bay and adjacent areas were highly affected by waning deglacial conditions in the Early Holocene with extensive sea-ice cover and ceasing meltwater influence from the marine outlet glaciers from the GIS.

Reconstructed mean July temperatures based on pollen records from lake cores point to colder than average air temperatures during the Early Holocene in both the eastern Canadian Arctic and north-west Greenland (a total of 13 sites) (Gajewski, 2015) (Fig. 7). These regions were subjected to cold air temperatures prior to $8.2 \mathrm{ka}$ due to the substantial remnants of the Laurentide Ice Sheet (LIS) cooling the adjacent areas and supplying them with meltwater (Barber et al., 1999; Jennings et al., 2015; Renssen et al., 2009). The widespread stratification in west Greenland and in Baffin Bay due to the increased meltwater supply is thought to have impeded deep-water formation in the Labrador Sea (Renssen et al., 2009; Seidenkrantz et al., 2013), resulting in a weaker northward flow of warmer air and water masses (Renssen et al., 2009). 


\subsection{Mid-Holocene}

The transition to warmer subsurface conditions was initiated around $7.9 \mathrm{ka}$ at our study site and marked by the increased abundances of Atlantic Water indicator species in the benthic foraminiferal assemblage, coinciding with low abundances of the sea-ice indicator species (Fig. 7). Additionally, the appearance of planktonic foraminifera and increase in the North Atlantic dinocyst taxa point to a warming of the surface waters (Caron et al., 2019). The warming of the subsurface waters in eastern Baffin Bay seems to have persisted for most of the mid-Holocene (7.9-2.9 ka); however, fluctuations in these conditions are evident. Benthic foraminiferal assemblage composition, and in particular the presence of C. neoteretis, indicates that this temperature increase was caused by a strengthening of the WGC related to stronger entrainment of Atlantic water masses from 7.9 to $6.7 \mathrm{ka}$, which was also observed in Kane Basin from 8.3 to 7.4 ka (Georgiadis et al., 2020). Concurrently, the appearance of the boreal subarctic mollusc Mytilus edulis in the coastal waters of Baffin Island around 8.7 to $3 \mathrm{ka}$ seems to support our interpretations of stronger advection of warmer Atlantic waters to the northern parts of Baffin Bay (Dyke et al., 1996), since Mytilus edulis today only appears in the southern regions of Greenland (Dyke et al., 1996). However, due to modern day climate and ocean warming this species is currently expanding its biogeographical distribution to the high Arctic (Berge et al., 2005; CAFF, 2013; Thyrring et al., 2015). Thus this species is a strong indicator for past changes in climate and ocean warming.

A concurrent shift in the oceanographic setting has also been identified west of Disko Bugt (core CC70; Fig. 8), where dinocyst assemblages imply an increasing sea surface temperature and a further reduction in seasonal sea-ice cover from a strengthened Atlantic Water inflow (Gibb et al., 2015). At the same site, the presence of benthic foraminiferal species associated with warm, subsurface water masses from $7.5 \mathrm{ka}$ was likely also facilitated by a decreased meltwater flow from the GIS together with an increased inflow of Atlantic water masses (Jennings et al., 2014).

South-west of Disko Bugt (core MSM343300; Fig. 8), evidence of warmer but variable subsurface water conditions is also here linked to an enhancement of warm WGC influence, observed in the benthic foraminiferal record at 7.3$6.2 \mathrm{ka}$ (Perner et al., 2012). At core site DA00-06 (Fig. 8) in Disko Bugt itself, a transition towards warmer conditions is marked by an increase in subarctic and Atlantic Water benthic foraminifera after $7.8 \mathrm{ka}$ (Lloyd et al., 2005). This is further supported by the combined multiproxy study (core MSM343300; Fig. 8) of Moros et al. (2016), where low abundances of sea-ice diatoms and dinocysts indicate that also surface water conditions were warmer and relatively stable, with low meltwater influx from the Greenland Ice Sheet linked to warmer air masses in central west Greenland. A similar decreasing meltwater release from ca. $7.5 \mathrm{ka}$ is also seen in the benthic foraminiferal record further south in Ameralik Fjord near Nuuk (core DA04-41P; Fig. 8) (Seidenkrantz et al., 2013). An oceanographic shift is also observed around 7.3 ka in the Labrador Sea (core MSM45-192 ), which experienced decreasing surface and bottom water temperatures in connection with a strengthened northward flowing branch of the WGC compared to a weakened westward deflection of the WGC (Lochte et al., 2019; Sheldon et al., 2016). Surface water reconstructions from the northernmost area of Baffin Bay (core 91-039-008P) and Newfoundland, i.e. the path of the Baffin Current and Labrador Current, show that increased advection of freshwater from melting Canadian Arctic glaciers strengthened the Baffin Current and Labrador Current (Levac et al., 2001; Solignac et al., 2011). This shift in the flow of the warmer WGC causing an opposite pattern between the western Labrador Sea (core MSM45-19-2) and eastern Baffin Bay/central west Greenland (cores CC70, MSM343300, DA00-06, DA0414P; Fig. 8) was likely fostered by a strengthening of the subpolar gyre (SPG) as a result of the commencement of deep-water formation in the Labrador Sea at $7.5 \mathrm{ka}$ (HillaireMarcel et al., 2001) after the strong meltwater fluxes from the GIS ceased. Warmer northward advection of Atlantic water masses along the coast of west Greenland and a stronger LC flow off eastern Canada are both patterns typical for a strong SPG (Sheldon et al., 2016). General Northern Hemisphere warming causing the melting of Canadian Arctic glaciers and thus meltwater release to the Baffin Current and the Labrador Current would also strengthen this pattern (Solignac et al., 2011).

The generally warmer mid-Holocene subsurface conditions at AMD14-204C were temporarily interrupted by a drop in the advection of warmer Atlantic water masses at $6.7 \mathrm{ka}$ when the abundances of the Atlantic Water benthic foraminiferal indicator species decreased temporarily. Here, Caron et al. (2018) observed a high IRD concentration at $6.7 \mathrm{ka}$ (Fig. 6). It also coincides with low North Atlantic dinocyst taxon abundances (Caron et al., 2019), high sedimentation rates, and a peak in the $\mathrm{Ca} / \mathrm{Ti}$ and $\mathrm{Ca} / \mathrm{Sr}$ elemental ratios, together with high abundances of sea-ice indicator species in our study, suggesting overall cold surface and subsurface water conditions. Supporting this, a biomarker record from a core in very close proximity to our study site shows a pronounced peak in the sea-ice edge biomarker HBI III around 7.0-6.3 ka, suggesting increased phytoplankton productivity and winter ice-edge conditions according to the authors Saini et al. (2020). Palaeozoic limestones and dolostones are commonly found at the flanks of the Nares Strait and Lancaster Sound in the northern part of Baffin Bay (Hiscott et al., 1989), whereas the north-western coast of Greenland consists of fold belts consisting of reworked Archean basement rocks (mainly gneisses) interfolded with overlying sediment sequences (marble, schist, and quartzite) and granitic intrusions (Henriksen, 2005). Older carbonate-rich layers are found in Baffin Bay marine deposits as a result 
of ice rafting in northern Baffin Bay, which are then exported southward with the BC (Andrews et al., 2011). The IRD found in this core was presumably exported from the Nares Strait or Lancaster Sound by increased incursion of polar water masses from the Arctic Ocean being transported southward by the BC, after which it recirculated eastwards to eastern Baffin Bay, which has previously been suggested for older marine records (Andrews et al., 2011; Jackson et al., 2017). Adding to this, the eastward transport of IRD was possibly fostered by a strengthening of the north-westerly winds due to the decrease in high-latitude insolation after $7 \mathrm{ka}$ (Renssen et al., 2005). Supporting this, Lancaster Sound was subjected to full cold Arctic conditions with enhanced sea-ice cover from 7.2 to $6.5 \mathrm{ka}$ (Pieñkowski et al., 2014), and northern Baffin Bay experienced colder summer surface water temperatures (Fig. 8; core 91-039-008P). Ca-rich IRD derived from the Marmorilik Formation comprising dolomite and calcite marbles from the Uummannaq fjord area may have contributed to the elevated $\mathrm{Ca}$ counts as well (Garde, 1979; Giraudeau et al., 2020). However, in Disko Bugt there are no signs of surface and subsurface water cooling (Fig. 7) (Moros et al., 2016; Perner et al., 2012; Erbs-Hansen et al., 2013), suggesting a local cooling of northern Baffin Bay.

A return to a period with warmer subsurface waters in eastern Baffin Bay is facilitated by a restrengthening of the WGC and Atlantic Water entrainment from 6.2 to $5.3 \mathrm{ka}$, which is inferred from the reappearance of high abundances of Atlantic Water indicator species in our study. The low abundance of the Atlantic Water indicator species I. norcrossi at around $6 \mathrm{ka}$ in core MSM343300 (Fig. 7) implies a cooling of the subsurface waters. However, the low abundance of I. norcrossi here might have been caused by other factors such as changes in nutrients availability, since other records in the Disko Bugt and central west Greenland areas do not record a prominent subsurface water cooling at that time (Erbs-Hansen et al., 2013; Jennings et al., 2014; Lloyd et al., 2005).

Another drop in the WGC strength is evident at $5.3 \mathrm{ka}$ at our study site, allowing the incursion of both polar surface waters and BBDW, as deduced by the high agglutinated / calcareous ratio observed in this study. This event corresponds to the onset of a general decrease in the July air temperatures over the eastern Canadian Arctic (Fig. 7) (Gajewski, 2015), followed by generally stable air temperatures above average until ca. $2.5 \mathrm{ka}$. Following this shortterm advection of BBDW advection, a restrengthening of the WGC is observed. A core in Ameralik Fjord also recorded enhanced inflow of saline WGC bottom waters at 4.4-3.2 ka, deduced from the sedimentary and benthic foraminiferal record, leading to the melting of the Greenland Ice Sheet margin causing surface water freshening (Møller et al., 2006; Seidenkrantz et al., 2007).

In general, the two periods with strong WGC flow associated with enhanced Atlantic Water incursion around 7.4 ka and again at $6.0 \mathrm{ka}$ observed at our study site seem to occur simultaneously with increasing July air temperatures over the eastern Canadian Arctic (Fig. 7) (Gajewski, 2015).

The general subsurface conditions in eastern Baffin Bay and west Greenland during the mid-Holocene from 7.9 to ca. $2.9 \mathrm{ka}$ are thus affected by overall warmer conditions related to a strong northward flow of Atlantic water masses with minimal influx of meltwater from the GIS. These warmer conditions coincide with the Holocene Thermal Maximum (HTM), corresponding to the timing in the eastern Canadian Arctic (Kaufman et al., 2004) and observed in Greenland ice cores with peak warming at 7-6 ka (e.g. Dahl-Jensen et al., 1998; Johnsen et al., 2001). The delayed onset of the HTM in the eastern Canadian Arctic and eastern Baffin Bay is associated with the final collapse of the LIS (Kaufman et al., 2004).

\subsection{The Late Holocene}

The warm surface and subsurface conditions of eastern Baffin Bay during the HTM were followed by a period of sudden deteriorating bottom water conditions as inferred from the abrupt increase in the agglutinated / calcareous foraminiferal species ratio, together with the presence of few Atlantic Water indicator species and low abundances of planktonic foraminifera, which is attributed to an enhanced BBDW advection to the core site. The green record in Fig. 7 shows that the distribution of agglutinated species does not increase significantly at the transition to this ecozone, whereas the abundance of the calcareous species (purple curve in Fig. 7) drops abruptly. This implies that the increase in the agglutinated / calcareous ratio is not an artefact of a low abundance of agglutinated species downcore due to poor preservation but that it is in fact attributed to a true oceanographic change. A marine sediment core from the southern Nares Strait also recorded this abrupt shift towards a benthic foraminiferal fauna dominated by agglutinated species around $3 \mathrm{ka}$ (Knudsen et al., 2008). The authors also explained this by an enhanced influence of Arctic Ocean water masses. Several studies from various parts of Baffin Bay have in fact documented this increased Arctic Ocean water incursion but at various times with the earliest at $8 \mathrm{ka}$ and the latest at ca. $3 \mathrm{ka}$ (Aksu, 1983; Jennings, 1993; Osterman et al., 1985; Osterman and Nelson, 1989). Based on previous studies, together with findings in our study, it can be deduced that the timing of the incursion of high-saline, cold, $\mathrm{CO}_{2}$-rich Arctic water masses occurred in the deeper central part of Baffin Bay first and later in the shallower coastal areas, as suggested by Knudsen et al. (2008).

The cold BBDW does not reach the Disko Bugt at water depths greater than $300 \mathrm{~m}$ today (Andersen, 1981); however, cold conditions are also evident here. Perner et al. (2012) recorded an increase in the abundances of agglutinated and Arctic water foraminifera at $3.5 \mathrm{ka}$, and they suggested that this was caused by a freshening of the bottom waters due to an increased entrainment of the EGC into the WGC and a less 
significant Atlantic Water entrainment. This agrees well with the low abundances of Atlantic Water indicator species found in our study, possibly attributed to a weaker AMOC. Concurrently, also the surface waters in Disko Bugt were cold in the Late Holocene (Moros et al., 2016), suggesting a general cooling trend of the subsurface and surface water temperatures in west Greenland (Andresen et al., 2011; Erbs-Hansen et al., 2013; Lloyd et al., 2007; Seidenkrantz et al., 2007, 2008). An increased outflow of polar waters from the Arctic Ocean, resulting in a strengthening and cooling of the Baffin Current and Labrador Current, is documented in cores CC70 and MSM45-19-2 from the Labrador Shelf (Fig. 8), where dinocyst and benthic foraminiferal assemblages document a surface and subsurface water cooling after $3 \mathrm{ka}$ (Gibb et al., 2015; Lochte et al., 2019). However, in the south-western Labrador Sea, surface and subsurface water amelioration are recorded by dinocyst and benthic foraminiferal data around $2.8 \mathrm{ka}$ (Sheldon et al., 2016; Solignac et al., 2011). This indicates an increasing influence from warmer Atlantic water masses versus the colder LC water masses due to a northward placement of the frontal zone between the Gulf Stream and the LC (Sheldon et al., 2016), thus implying that the outflow of cold Arctic Ocean waters did not reach the south-eastern Labrador Sea.

The general cooling trend recorded in the marine records described here is also observed in the pollen records from the eastern Canadian Arctic and north Greenland with July air temperatures being lower than average starting at 1.5 and $2.8 \mathrm{ka}$, respectively (Fig. 7) (Gajewski, 2015). This general cooling trend observed in vast areas of the North Atlantic in the Late Holocene corresponds to the neoglaciation and is linked to the initiation of readvances in many of the glaciers and ice streams in west Greenland, including the Upernavik Isstrøm (Briner et al., 2013). An advance of the Upernavik Isstrøm could explain the higher IRD counts in this ecozone, which are related to increased iceberg calving. However, it seems that the onset of the cold subsurface conditions in eastern Baffin Bay recorded in our study is not fully synchronous with the change towards colder summer air temperatures in the eastern Canadian Arctic. Nevertheless, the onset of the cold neoglacial in eastern Baffin Bay resembles the onset of colder air temperatures recorded in north Greenland, possibly related to the enhanced inflow of the cold Arctic water masses, subjecting eastern Baffin Bay to high-latitude conditions like the conditions in north Greenland. This is further supported by findings of driftwood in the Canadian Arctic Archipelago (CAA), caused by a westward deflected Transpolar Drift, pushing cold polar water masses through the gateways of the CAA (Dyke et al., 1997).

Superimposed on the neoglacial cooling, shorter temporal subsurface water ameliorations are evident in eastern Baffin Bay, here associated with a restrengthening of the WGC and Atlantic Water inflow centred at 1.6, 1.2, and $0.8 \mathrm{ka}$. These peaks in the Atlantic Water group are seen in both curves representing the percentage distribution of this group. How- ever, the percentages calculated without including the agglutinated species are quite high and not reliable since the total sum of calcareous benthic foraminifera here are too low to be statistically significant for interpretation.

In Disko Bugt the Late Holocene is characterized by shortlived warmings of both the surface and subsurface waters, which is related to an enhanced IC advection (Andresen et al., 2011; Lloyd, 2006; Moros et al., 2006, 2016; Perner et al., 2012). Records from the Labrador Sea have also documented these warmings from 2.0 to $1.5 \mathrm{ka}$, which are indicated by fluctuating lengths of the sea-ice seasons (Lochte et al., 2019). They coincide with shorter warmings found in Placentia Bay in Newfoundland (Solignac et al., 2011) and in the shelf waters of east Greenland (Jennings et al., 2002). These widespread, Late Holocene, centennial-scale climate fluctuations were presumably facilitated by fluctuations in the atmospheric circulation pattern over the North Atlantic, which controlled the strength of the north-westerly winds. However, a higher temporal resolution is needed in order to fully resolve these short-term climatic fluctuations documented in this study and other studies from the North Atlantic.

\section{Conclusion}

The presented multiproxy study, based on benthic foraminiferal assemblage analysis and X-ray fluorescence data, documents several climatic and oceanographic changes in eastern Baffin Bay during the Holocene:

1. Eastern Baffin Bay was subjected to cold deglacial conditions in the Early Holocene $(9.2-7.9 \mathrm{ka})$, associated with an extensive sea-ice cover and meltwater inflows supplied by the melting of the Greenland Ice Sheet. Subsurface water conditions are characterized by a very low benthic foraminiferal species diversity and the coeval low abundances of Atlantic Water indicator species, reflecting a low entrainment of Atlantic Water into the West Greenland Current.

2. A transition towards warmer subsurface water conditions is evident at the onset of the mid-Holocene (7.9 ka), encompassing the Holocene Thermal Maximum, when eastern Baffin Bay was subjected to a strengthening of the West Greenland Current flow, which was related to an increased Atlantic Water incursion and ceasing meltwater influxes from the Greenland Ice Sheet. The ameliorating conditions found here are linked to a widespread oceanographic shift in the North Atlantic due to the commencement of deep-water formation in the Labrador Sea.

3. The general ameliorating conditions found in the midHolocene were interrupted by a cooling period centred at $6.7 \mathrm{ka}$, deduced from high abundances of sea-ice indicator species and high IRD counts. The latter presumably originated from the gateways of the Canadian 
Arctic Archipelago, which is inferred from the high Ca content observed in the XRF data. This cold period is attributed to a weakening of the subpolar gyre, facilitating a weakening of the northward flowing Atlantic water masses along the west Greenland coast.

4. Evidence of enhanced inflow of the cold, corrosive, and dense Baffin Bay Deep Water is documented at $5.3 \mathrm{ka}$, reflected in the low abundances of the calcareous benthic species together with a decrease in the abundances of the Atlantic Water indicator species. This is concurrent with a drop in the estimated July air temperatures found in the eastern Arctic.

5. A drastic shift in the ocean circulation system occurred around $2.9 \mathrm{ka}$, which is attributed to the onset of the neoglacial cooling. Eastern Baffin Bay was subjected to an enhanced southward inflow of cold, corrosive, and dense Baffin Bay Deep Water, which is demonstrated by the domination of agglutinated benthic foraminifera.

6. Short-lived bottom water warmings superimposed on the neoglacial cooling characterize the latest part of the Holocene, possibly facilitated by fluctuations in the atmospheric circulation system affecting the strength of the north-westerly winds.

Data availability. Benthic foraminiferal abundance data can be accessed at PANGAEA or by corresponding with Katrine Elnegaard Hansen (katrine.elnegaard@ geo.au.dk) or Marit-Solveig Seidenkrantz (mss@geo.au.dk).

Supplement. The supplement related to this article is available online at: https://doi.org/10.5194/cp-16-1075-2020-supplement.

Author contributions. MSS developed the research idea. KEH conducted the benthic foraminiferal assemblage analysis with major contributions from MSS. LW carried out the seven additional radiocarbon datings. JG provided four radiocarbon datings. CP performed the age modelling of the core. KEH prepared the paper with contributions from all co-authors.

Competing interests. Author Marit-Solveig Seidenkrantz is coeditor-in-chief of the journal.

Acknowledgements. We are grateful to the captain, crew and scientific party of the CCGS Amundsen 2014 expedition for their work in retrieval of sediment core AMD14-204C with financial support by the Fondation Total, the French Agence Nationale de la Recherche (GreenEdge project), the Network of Centres of Excellence ArcticNet, and the ERC STG ICEPROXY 203441. We also thank Guillaume Massé for the opportunity to work on the marine sediment core AMD14-204C. We also wish to thank Eleanor Georgiadis, Philippe Martinez, and Isabelle Billy for running the X-ray fluorescence spectroscopy of the core at the EPOC laboratory in Bordeaux, and for composing these data sets. We also thank Myriam Caron for the dinocyst, IRD, and grain size data sets.

Financial support. This research has been supported by the Danish Council for Independent Research (grant no. 701400113B/FNU) to Marit-Solveig Seidenkrantz (G-Ice project).

Review statement. This paper was edited by David Thornalley and reviewed by John Andrews and one anonymous referee.

\section{References}

Aksenov, Y., Bacon, S., Coward, A. C., and Holliday, N. P.: Polar outflow from the Arctic Ocean: A high resolution model study, J. Mar. Syst., 83, 14-37, https://doi.org/10.1016/j.jmarsys.2010.06.007, 2010.

Aksu, A.: Late Quaternary Stratigraphy, Palaeoenvironmentology and Sedimentation History of Baffin Bay and Davis Strait, Dallhouse University, Halifax, Nova Scotia, 1981.

Aksu, A.: Holocene and Pleistocene dissolution cycles in deapsea cores of Baffin Island and Davies Strait: Paleoceanographic implications, Mar. Geol., 53, 331-348, 1983.

Andersen, O. G. N.: The annual cycle of temperature, salinity, currents and water masses in Disko Bugt and adjacent waters, West Greenland, Meddelelser om Grønland, Bioscience, 5, 1-36, 1981.

Andresen, C. S., McCarthy, D. J., Dylmer, C. V., Seidenkrantz, M. S., Kuijpers, A., and Lloyd, J. M.: Interaction between subsurface ocean waters and calving of the Jakobshavn Isbræ during the late Holocene, Holocene, 21, 211-224, https://doi.org/10.1177/0959683610378877, 2011.

Andresen, C. S., Kjeldsen, K. K., Harden, B., Nørgaard-Pedersen, N., and Kjær, K. H.: Outlet glacier dynamics and bathymetry at Upernavik, GEUS Bullitin, 31, 81-84, 2014.

Andrews, J. T., Eberl, D. D., and Scott, D.: Surface (sea floor) and near-surface (box cores) sediment mineralogy in Baffin Bay as a key to sediment provenance and ice sheet variations, Can. J. Earth Sci., 48, 1307-1328, https://doi.org/10.1139/e11-021, 2011.

Bahr, A., Lamy, F., Arz, H., Kuhlmann, H., and Wefer, G.: Late glacial to Holocene climate and sedimentation history in the NW Black Sea, Mar. Geol., 214, 309-322, https://doi.org/10.1016/j.margeo.2004.11.013, 2005.

Barber, D. C., Dyke, A., Hillaire-Marcel, C., Jennings, A. E., Andrews, J. T., Kerwin, M. W., Bilodeau, G., McNeely, R., Southon, J., Morehead, M. D., and Gagnon, J. M.: Forcing of the cold event of 8,200 years ago by catastrophic drainage of Laurentide lakes, Nature, 400, 344-348, https://doi.org/10.1038/22504, 1999.

Berge, J., Johnsen, G., Nilsen, F., Gulliksen, B., and Slagstad, D.: Ocean temperature oscillations enable reappearance of blue mussels Mytilus edulis in Svalbard after a 1000 year absence, Mar. Ecol. Prog. Ser., 303, 167-175, https://doi.org/10.3354/meps303167, 2005. 
Bi, H., Zhang, Z., Wang, Y., Xu, X., Liang, Y., Huang, J., Liu, Y., and Fu, M.: Baffin Bay sea ice inflow and outflow: 1978-1979 to 2016-2017, The Cryosphere, 13, 1025-1042, https://doi.org/10.5194/tc-13-1025-2019, 2019.

Bourke, R. H. and Paquette, R. G.: Formation of Baffin Bay bottom and deep waters, in: Deep convection and deep water formation in the oceans, edited by: Chu, J. C. and Gascard, P. C., pp. 135155, Elsevier, Amsterdam, 1991.

Briner, J. P., Håkansson, L., and Bennike, O.: The deglaciation and neoglaciation of upernavik isstrøm, greenland, Quaternary Res., 80, 459-467, https://doi.org/10.1016/j.yqres.2013.09.008, 2013.

Buch, E.: A monograph on the physical oceanography of the Greenland waters, Royal Danish Administration of Navigation and Hydrography, Copenhagen, 1994.

Bunker, A. F.: Computations of Surface Energy Flux and Annual Air-Sea Interaction Cycles of the North Atlantic Ocean, Mon. Weather Rev., 104, 1122-1140, https://doi.org/10.1175/15200493(1976)104<1122:cosefa>2.0.co;2, 1976.

CAFF: Arctic Biodiversity Assessment: Status and trends in Arctic biodiversity, edited by: Meltofte, H., CAFF International Secretariat, Akureyri, ISBN 978-9935-431-22-6, 2013.

Calvert, S. E. and Pedersen, T. F.: Geochemistry of Recent oxic and anoxic marine sediments: Implications for the geological record, Mar. Geol., 113, 67-88, https://doi.org/10.1016/00253227(93)90150-T, 1993.

Canadian Coast Guard: Chapter 3 Ice Climatology and Environmental Conditions, in Ice Navigation in Canadian Waters, Canadian Coast Guard, p. 69, Icebreaking Program, Maritime Services, Canadian Coast Guard Fisheries and Oceans Canada, Ottawa, Ontario, Canada, available at: https://www.ccg-gcc.gc. ca/publications/icebreaking-deglacage/ice-navigation-glaces/ docs/ice-navigation-dans-les-galces-eng.pdf (last access: 15 July 2019), 2012.

Caron, M., St-Onge, G., Montero-Serrano, J. C., Rochon, A., Georgiadis, E., Giraudeau, J., and Massé, G.: Holocene chronostratigraphy of northeastern Baffin Bay based on radiocarbon and palaeomagnetic data, Boreas, 48, 147-165, https://doi.org/10.1111/bor.12346, 2018.

Caron, M., Rochon, A., Carlos, J., Serrano, M., and Onge, G. S. T.: Evolution of sea-surface conditions on the northwestern Greenland margin during the Holocene, J. Quaternar Sci., 34, 1-12, https://doi.org/10.1002/jqs.3146, 2019.

Castro de la Guardia, L., Hu, X., and Myers, P. G.: Potential positive feedback between Greenland Ice Sheet melt and Baffin Bay heat content on the west Greenland shelf, Geophys. Res. Lett., 42, 4922-4930, https://doi.org/10.1002/2015GL064626, 2015.

Collin, A. E.: Oceanographic observations in Nares Strait, Northern Baffin Bay, 1963, 1964, Bedford Institute of Oceanography, Report B.I.O. 65-5, 9 pp., 1965.

Cuny, J., Rhines, P. B., Niiler, P. P., and Bacon, S.: Labrador Sea Boundary Currents and the Fate of the Irminger Sea Water, J. Phys. Oceanogr., 32, 627-647, https://doi.org/10.1175/15200485(2002)032<0627:LSBCAT>2.0.CO;2, 2002.

Dahl-Jensen, D., Mosegaard, K., Gundestrup, N., Clow, G. D., Johnsen, S. J., Hansen, A. W., and Balling, N.: Past temperatures directly from the Greenland Ice Sheet, Science, 282, 268-271, https://doi.org/10.1126/science.282.5387.268, 1998.
Drinkwater, K. F.: Atmospheric and oceanic variability in the northwest Atlantic during the 1980s and early 1990s, J. Northwest Atl. Fish. Sci., 18, 77-97, https://doi.org/10.2960/J.v18.a6, 1996.

Dunbar, M. and Dunbar, M. J.: The history of the North Water, Proc. R. Soc. Edinburgh, Sect. B Biol. Sci., 72, 231-241, 1972.

Dyke, A. S.: An outline of North American deglaciation with emphasis on central and northern Canada, in: Quaternary Glaciations - Extent and Chronology. 2, edited by: Ehlers, J. and Gibbard, P. L., Elsevier, Amsterdam, pp. 371-406, https://doi.org/10.1016/S1571-0866(04)80209-4, 2004.

Dyke, A. S., Dale, J. E., and McNeely, R. N.: Marine Molluscs as Indicators of Environmental Change in Glaciated North America and Greenland During the Last 18000 YearsLes mollusques marins et les changements du milieu dans la partie englacée de l'Amérique du Nord et du Groenland depuis 18000 ans Me, Géographie Phys. Quat., 50, 125-184, https://doi.org/10.7202/033087ar, 1996.

Dyke, A. S., England, J., Reimnitz, E. R. K., and Jette, H.: Changes in Driftwood Delivery to the Canadian Arctic Archipelago?: The Hypothesis of Postglacial Oscillations of the Transpolar Drift, Arctic, 50, 1-16, 1997.

Eirksson, J., Knudsen, K. L., Haflidason, H., and Heinemeier, J.: Chronology of late Holocene climatic events in the northern North Atlantic based on AMS ${ }^{14} \mathrm{C}$ dates and tephra markers from the volcano Hekla, Iceland, J. Quaternary Sci., 15, 573-580, https://doi.org/10.1002/10991417(200009)15:6<573::AID-JQS554>3.0.CO;2-A, 2000.

England, J., Atkinson, N., Bednarski, J., Dyke, A. S., Hodgson, D. A., and Ó Cofaigh, C.: The Innuitian Ice Sheet: configuration, dynamics and chronology, Quaternary Sci. Rev., 25, 689-703, https://doi.org/10.1016/j.quascirev.2005.08.007, 2006.

Erbs-Hansen, D., Reng Knudsen, K. L., Olsen, J., Lykke-Andersen, H., Underbjerg, J. A., and Sha, L.: Paleoceanographical development off Sisimiut, West Greenland, during the mid- and late Holocene: A multiproxy study, Mar. Micropaleontol., 102, 7997, https://doi.org/10.1016/j.marmicro.2013.06.003, 2013.

Funder, S. (Ed.): Late Quaternary stratigraphy and glaciology in the Thule area, Northwest Greenland, Meddelelser om Grønland, Geosci., 22, 1-63, 1990.

Gajewski, K.: Quantitative reconstruction of Holocene temperatures across the Canadian Arctic and Greenland, Glob. Planet. Change, 128, 14-23, https://doi.org/10.1016/j.gloplacha.2015.02.003, 2015.

Garde, A. A.: Strontium geochemistry and carbon and oxygen isotopic compositions of lower proterozoic dolomite and calcite marbles from the Marmorilik Formation, West Greenland, Precambrian Res., 8, 183-199, https://doi.org/10.1016/03019268(79)90028-7, 1979.

Georgiadis, E., Giraudeau, J., Martinez, P., Lajeunesse, P., StOnge, G., Schmidt, S., and Massé, G.: Deglacial to postglacial history of Nares Strait, Northwest Greenland: a marine perspective from Kane Basin, Clim. Past, 14, 1991-2010, https://doi.org/10.5194/cp-14-1991-2018, 2018.

Georgiadis, E., Giraudeau, J., Jennings, A., Limoges, A., Jackson, R., Ribeiro, S., and Massé, G.: Local and regional controls on Holocene sea ice dynamics and oceanography in Nares Strait, Northwest Greenland, Mar. Geol., 422, 106115, https://doi.org/10.1016/j.margeo.2020.106115, 2020. 
Gibb, O. T., Steinhauer, S., Fréchette, B., de Vernal, A., and Hillaire-Marcel, C.: Diachronous evolution of sea surface conditions in the labrador sea and baffin bay since the last deglaciation, Holocene, 25, 1882-1897, https://doi.org/10.1177/0959683615591352, 2015.

Giraudeau, J., Georgiadis, E., Caron, M., Martinez, P., Saint-Onge, G., Billy, I., Lebleu, P., Ther, O., and Massé, G.: A highresolution elemental record of post-glacial lithic sedimentation in Upernavik Trough, western Greenland: history of ice-sheet dynamics and ocean circulation changes over the last 9100 years, Glob. Planet. Change, 191, 1-14, 2020.

Gustafsson, M. and Nordberg, K.: Living (stained) benthic foraminiferal response to primary production and hydrography in the deepest part of the Gullmar Fjord, Swedish West Coast, with comparisons to Hoglund's 1927 material, J. Foramin. Res., 31, 2-11, https://doi.org/10.2113/0310002, 2001.

Henriksen, N.: Geological History of Greenland - Four billion years of Earth evolution, Geological Survey of Denmark and Greenland (GEUS), Copenhagen, 2005.

Hillaire-Marcel, C., DeVernal, A., Bilodeau, G., and Weaver, A. J.: Absence of deep-water formation in the Labrador Sea during the last interglacial period, Nature, 410, 1073-1077, 2001.

Hiscott, R. N., Aksu, A. E., and Nielsen, O. B.: Provenance and dispersal patterns, Pliocene-Pleistocene section at Site 645, Baffin Bay, in: Proc. ODP, Sci. Results, edited by: Littleton, R. M., College Station, TX (Ocean Drilling Program), 105, 31-52, https://doi.org/10.2973/odp.proc.sr.105.117.1989, 1989.

Holland, D. M., Thomas, R. H., De Young, B., Ribergaard, M. H., and Lyberth, B.: Acceleration of Jakobshavn Isbr triggered by warm subsurface ocean waters, Nat. Geosci., 1, 659-664, https://doi.org/10.1038/ngeo316, 2008.

Jackson, R., Carlson, A. E., Hillaire-Marcel, C., Wacker, L., Vogt, C., and Kucera, M.: Asynchronous instability of the North American-Arctic and Greenland ice sheets during the last deglaciation, Quaternary Sci. Rev., 164, 140-153, https://doi.org/10.1016/j.quascirev.2017.03.020, 2017.

Jennings, A., Andrews, J., Pearce, C., Wilson, L., and Ólfasdótttir, S.: Detrital carbonate peaks on the Labrador shelf, a $13-7 \mathrm{ka}$ template for freshwater forcing from the Hudson Strait outlet of the Laurentide Ice Sheet into the subpolar gyre, Quaternary Sci. Rev., 107, 62-80, https://doi.org/10.1016/j.quascirev.2014.10.022, 2015.

Jennings, A. E.: The Quaternary History of Cumberland Sound, Southeastern Baffin-Island - the Marine Evidence, Geogr. Phys. Quat., 47, 21-42, 1993.

Jennings, A. E. and Helgadottir, G.: Foraminiferal assemblages from the fjords and shelf of eastern Greenland, J. Foramin. Res., 24, 123-144, 1994.

Jennings, A. E., Andrews, J. T., Knudsen, K. L., Hansen, C. V., and Hald, M.: A mid-Holocene shift in Arctic sea-ice variability on the East Greenland Shelf, Holocene, 12, 49-58, https://doi.org/10.1191/0959683602hl519rp, 2002.

Jennings, A. E., Weiner, N. J., and Helgadottir, G.: Modern foraminiferal faunas of the southwestern to northern Iceland shelf: Oceanographic and environmental controls, J. Foramin. Res., 34, 180-207, https://doi.org/10.2113/34.3.180, 2004.

Jennings, A. E., Sheldon, C., Cronin, T., Francus, P., Stoner, J. S., and Andrews, J.: The Holocene History of Nares Strait, Oceanography, 24, 26-41, 2011.
Jennings, A. E., Ó Cofaigh, C., Ortiz, J. D., De Vernal, A., Dowdeswell, J. A., Kilfeather, A., Walton, M. E., and Andrews, J.: Paleoenvironments during Younger Dryas-Early Holocene retreat of the Greenland Ice Sheet from outer Disko Trough, central west Greenland, J. Quaternary Sci., 29, 27-40, https://doi.org/10.1002/jqs.2652, 2014.

Jennings, A. E., Andrews, J. T., Ó Cofaigh, C., Onge, G. S., Sheldon, C., Belt, S. T., Cabedo-Sanz, P., and Hillaire-Marcel, C.: Ocean forcing of Ice Sheet retreat in central west Greenland from LGM to the early Holocene, Earth Planet. Sc. Lett., 472, 1-13, https://doi.org/10.1016/j.epsl.2017.05.007, 2017.

Jennings, A. E., Andrews, J. T., Ó Cofaigh, C., St-Onge, G., Belt, S., Cabedo-Sanz, P., Pearce, C., Hillaire-Marcel, C., and Calvin Campbell, D.: Baffin Bay paleoenvironments in the LGM and HS1: Resolving the ice-shelf question, Mar. Geol., 402, 5-16, https://doi.org/10.1016/j.margeo.2017.09.002, 2018.

Jennings, A. E., Andrews, J. T., Oliver, B., Walczak, M., and Mix, A.: Retreat of the Smith Sound Ice Stream in the Early Holocene, Boreas, 1-16, https://doi.org/10.1111/bor.12391, 2019.

Johnsen, S. J., Dahl-Jensen, D., Gundestrup, N., Steffensen, J. P., Clausen, H. B., Miller, H., Masson-Delmotte, V., Sveinbjörnsdottir, A. E., and White, J.: Oxygen isotope and palaeotemperature records from six Greenland ice-core stations: Camp Century, Dye-3, GRIP, GISP2, Renland and NorthGRIP, J. Quaternary Sci., 16, 299-307, https://doi.org/10.1002/jqs.622, 2001.

Jones, E. P. and Anderson, L. G.: Is the global conveyor belt threatened by arctic ocean fresh water outflow?, in: Arctic-Subarctic Ocean Fluxes: Defining the Role of the Northern Seas in Climate, edited by: Dickson, R. R. Meincke,, J., and Rhines, P., pp. 385-404, Springer, Dordrecht (the Netherlands), 2008.

Kaufman, D. S., Ager, T. A., Anderson, N. J., Anderson, P. M., Andrews, J. T., Bartlein, P. J., Brubaker, L. B., Coats, L. L., Cwynar, L. C., Duvall, M. L., Dyke, A. S., Edwards, M. E., Eisner, W. R., Gajewski, K., Geirsdóttir, A., Hu, F. S., Jennings, A. E., Kaplan, M. R., Kerwin, M. W., Lozhkin, A. V., MacDonald, G. M., Miller, G. H., Mock, C. J., Oswald, W. W., Otto-Bliesner, B. L., Porinchu, D. F., Rühland, K., Smol, J. P., Steig, E. J., and Wolfe, B. B.: Holocene thermal maximum in the western Arctic $\left(0-180^{\circ} \mathrm{W}\right)$, Quaternay Sci. Rev., 23, 529-560, https://doi.org/10.1016/j.quascirev.2003.09.007, 2004.

Knudsen, K. L. and Seidenkrantz, M.-S.: Stainforthia feylingi new species from arctic to subarctic environments, previously recorded as Stainforthia schreibersiana, Cushman Found. Foraminifer. Res. Spec. Publ., 32, 5-13, 1994.

Knudsen, K. L., Conradsen, K., Heier-Nielsen, S., and Seidenkrantz, M. S.: Palaeoenvironments in the SkagerrakKattegat basin in the eastern North Sea during the last deglaciation, Boreas, 25, 65-78, https://doi.org/10.1111/j.15023885.1996.tb00836.x, 1996.

Knudsen, K. L., Stabell, B., Seidenkrantz, M. S., Eiríksson, J., and Blake, W.: Deglacial and Holocene conditions in northernmost Baffin Bay: Sediments, foraminifera, diatoms and stable isotopes, Boreas, 37-, 346-376, https://doi.org/10.1111/j.15023885.2008.00035.x, 2008.

Korsun, S. and Hald, M.: Modern Benthic Foraminifera off Novaya Zemlya Tidewater Glaciers, Russian Arctic, Arct. Alp. Res., 30, 61-77, https://doi.org/10.2307/1551746, 1998.

Korsun, S. and Hald, M.: Seasonal dynamics of benthic foraminifera in a glacially fed fjord of Sval- 
bard, European Arctic, J. Foramin. Res., 30, 251-271, https://doi.org/10.2113/0300251, 2000.

Levac, E., De Vernal, A., and Blake, W.: Sea-surface conditions in northernmost Baffin Bay during the Holocene: Palynological evidence, J. Quaternary Sci., 16, 353-363, https://doi.org/10.1002/jqs.614, 2001.

Lloyd, J., Moros, M., Perner, K., Telford, R. J., Kuijpers, A., Jansen, E., and McCarthy, D.: A 100 yr record of ocean temperature control on the stability of Jakobshavn Isbrae, West Greenland, Geology, 39, 867-870, https://doi.org/10.1130/G32076.1, 2011.

Lloyd, J. M.: Late Holocene environmental change in Disko Bugt, west Greenland: Interaction between climate, ocean circulation and Jakobshavn Isbrae, Boreas, 35, 35-49, https://doi.org/10.1111/j.1502-3885.2006.tb01111.x, 2006.

Lloyd, J. M., Park, L. A., Kuijpers, A., and Moros, M.: Early Holocene palaeoceanography and deglacial chronology of Disko Bugt, West Greenland, Quaternary Sci. Rev., 24, 1741-1755, https://doi.org/10.1016/j.quascirev.2004.07.024, 2005.

Lloyd, J. M., Kuijpers, A., Long, A., Moros, M., and Park, L. A.: Foraminiferal reconstruction of mid- to lateHolocene ocean circulation and climate variability in Disko Bugt, West Greenland, Holocene, 17, 1079-1091, https://doi.org/10.1177/0959683607082548, 2007.

Locarnini, R. A., Mishonov, A. V, Antonov, J. I., Boyer, T. P., Garcia, H. E., Baranova, O. K., Zweng, M. M., Paver, C. R., Reagan, J. R., Johnson, D. R., Hamilton, M., and Seidov, D.: WORLD OCEAN ATLAS 2013: Temperature Volume 1, edited by: Mishonov, A., Technical Ed., NOAA Atlas NESDIS 73, 2013.

Lochte, A. A., Repschläger, J., Seidenkrantz, M.-S., Kienast, M., Blanz, T., and Schneider, R. R.: Holocene water mass changes in the Labrador Current, Holocene, 29, 676-690, 2019.

Melling, H., Gratton, Y., Ingram, G., Melling, H., Gratton, Y., and Ingram, G.: Ocean circulation within the North Water polynya of Baffin Bay Ocean Circulation within the North Water Polynya of Baffin Bay, Atmosphere-Ocean, 39, 301-325, https://doi.org/10.1080/07055900.2001.9649683, 2010.

Mertz, G., Narayanan, S., and Helbig, J.: The freshwater transport of the labrador current, Atmos.-Ocean, 31, 281-295, https://doi.org/10.1080/07055900.1993.9649472, 1993.

Møller, H. S., Jensen, K. G., Kuijpers, A., Aagaard-Sørensen, S., Seidenkrantz, M. S., Prins, M., Endler, R., and Mikkelsen, N.: Late-Holocene environment and climatic changes in Ameralik Fjord, southwest Greenland: Evidence from the sedimentary record, Holocene, 16, 685-695, https://doi.org/10.1191/0959683606h1963rp, 2006.

Morlighem, M., Williams, C. N., Rignot, E., An, L., Arndt, J. E., Bamber, J. L., Catania, G., Chauché, N., Dowdeswell, J. A., Dorschel, B., Fenty, I., Hogan, K., Howat, I., Hubbard, A., Jakobsson, M., Jordan, T. M., Kjeldsen, K. K., Millan, R., Mayer, L., Mouginot, J., Noël, B. P. Y., O'Cofaigh, C., Palmer, S., Rysgaard, S., Seroussi, H., Siegert, M. J., Slabon, P., Straneo, F., van den Broeke, M. R., Weinrebe, W., Wood, M., and Zinglersen, K. B.: BedMachine v3: Complete Bed Topography and Ocean Bathymetry Mapping of Greenland From Multibeam Echo Sounding Combined With Mass Conservation, Geophys. Res. Lett., 44, 11051-11061, https://doi.org/10.1002/2017GL074954, 2017.

Moros, M., Jensen, K. G., and Kuijpers, A.: Mid- to lateHolocene hydrological and climatic variability in Disko
Bugt, central West Greenland, Holocene, 16, 357-367, https://doi.org/10.1191/0959683606hl933rp, 2006.

Moros, M., Lloyd, J. M., Jennings, A. E., Krawczyk, D., Witkowski, A., Blanz, T., Kuijpers, A., Ouellet-Bernier, M.M., de Vernal, A., Schneider, R., Perner, K., and Jansen, E.: Surface and sub-surface multi-proxy reconstruction of middle to late Holocene palaeoceanographic changes in Disko Bugt, West Greenland, Quaternary Sci. Rev., 132, 146-160, https://doi.org/10.1016/j.quascirev.2015.11.017, 2016.

Münchow, A., Falkner, K. K., and Melling, H.: Baffin Island and West Greenland Current Systems in northern Baffin Bay, Prog. Oceanogr., 132, 305-317, https://doi.org/10.1016/j.pocean.2014.04.001, 2015.

Nagler, T., Rott, H., Hetzenecker, M., Wuite, J., and Potin, P.: The Sentinel-1 mission: New opportunities for ice sheet observations, Remote Sens., 7, 9371-9389, https://doi.org/10.3390/rs70709371, 2015.

NSIDC (National Snow and Ice Data Centre): Atlas Cryosph, available at: ftp://sidads.colorado.edu/DATASETS/NOAA/G02135/ north/monthly/shapefiles/shp_median/, last access: 30 October 2019.

Osterman, L. E. and Nelson, A. R.: Latest Quaternary and Holocene paleoceanography of the eastern Baffin Island continental shelf, Canada: benthic foraminiferal evidence, Can. J. Earth Sci., 26, 2236-2248, https://doi.org/10.1139/e89-190, 1989.

Osterman, L. E., Miller, G. H., and Stravers, J. A.: Late and midFoxe glaciation of southern Baffin Island, in: Quaternary Environments, Eastern Canadian Arctic, Baffin Bay and Western Greenland, edited by: Andrews, J. T., pp. 520-545, Allen \& Unwin, Londond., 1985.

Patterson, R. T., Guilbault, J. P., and Thomson, R. E.: Oxygen level control on foraminiferal distribution in Effingham Inlet, Vancouver Island, British Columbia, Canada, J. Foramin. Res., 30, 321335, https://doi.org/10.2113/0300321, 2000.

Perner, K., Moros, M., Lloyd, J. M., Kuijpers, A., Telford, R. J., and Harff, J.: Centennial scale benthic foraminiferal record of late Holocene oceanographic variability in Disko Bugt, West Greenland, Quaternary Sci. Rev., 30, 2815-2826, https://doi.org/10.1016/j.quascirev.2011.06.018, 2011.

Perner, K., Moros, M., Jennings, A., Lloyd, J. M., and Knudsen, K. L.: Holocene palaeoceanographic evolution off West Greenland, Holocene, 23, 374-387, https://doi.org/10.1177/0959683612460785, 2012.

Pieñkowski, A. J., England, J. H., Furze, M. F. A., MacLean, B., and Blasco, S.: The late Quaternary environmental evolution of marine Arctic Canada: Barrow Strait to Lancaster Sound, Quaternary Sci. Rev., 91, 184-203, https://doi.org/10.1016/j.quascirev.2013.09.025, 2014.

Polyak, L., Korsun, S., Febo, L. A., and Al, E.: Benthic foraminiferal assemblages from the southern Kara Sea, a riverinfluenced Arctic marine environment, J. Foramin. Res., 32, 252 273, https://doi.org/10.2113/32.3.252, 2002.

Pruysers, P. A., de Lange, G. J., and Middelburg, J. J.: Geochemistry of eastern Mediterranean sediments: Primary sediment composition and diagenetic alterations, Mar. Geol., 100, 137-154, https://doi.org/10.1016/0025-3227(91)90230-2, 1991.

Ramsey, C. B.: Deposition models for chronological records, Quaternary Sci. Rev., 27, 42-60, https://doi.org/10.1016/j.quascirev.2007.01.019, 2008. 
Reimer, P. J., Bard, E., Bayliss, A., Beck, J. W., Blackwell, P. G., Ramsey, C. B., Buck, C. E., Cheng, H., Edwards, R. L., Friedrich, M., Grootes, P. M., Guilderson, T. P., Haflidason, H., Hajdas, I., Hatté, C., Heaton, T. J., Hoffmann, D. L., Hogg, A. G., Hughen, K. A., Kaiser, K. F., Kromer, B., Manning, S. W., Niu, M., Reimer, R. W., Richards, D. A., Scott, E. M., Southon, J. R., Staff, R. A., Turney, C. S. M., and van der Plicht, J.: IntCal13 and Marine13 Radiocarbon Age Calibration Curves 0-50,000 Years cal BP, Radiocarbon, 55, 1869-1887, https://doi.org/10.2458/azu_js_rc.55.16947, 2013.

Renssen, H., Goosse, H., and Fichefet, T.: Contrasting trends in North Atlantic deep-water formation in the Labrador Sea and Nordic Seas during the Holocene, Geophys. Res. Lett., 32, L08711, https://doi.org/10.1029/2005GL022462, 2005.

Renssen, H., Seppä, H., Heiri, O., Roche, D. M., Goosse, H., and Fichefet, T.: The spatial and temporal complexity of the holocene thermal maximum, Nat. Geosci., 2, 411-414, https://doi.org/10.1038/ngeo513, 2009.

Richter, T. O., Gaast, S. van der, Koster, B., Vaars, A., Gieles, R., de Stigter, H. C., De Haas, H., and van Weering, T. C. E.: The Avaatech XRF Core Scanner: technical description and applications to NE Atlantic sediments, Geol. Soc. London, Spec. Publ., 267, 3950, https://doi.org/10.1144/GSL.SP.2006.267.01.03, 2005.

Rignot, E., Koppes, M., and Velicogna, I.: Rapid submarine melting of the calving faces of West Greenland glaciers, Nat. Geosci., 3, 187-191, https://doi.org/10.1038/ngeo765, 2010.

Rothwell, R. G. and Croudace, I. W.: Micro-XRF Studies of Sediment Cores: A Perspective on Capability and Application in the Environmental Sciences, Springer, Dordrecht, 2015.

Rykova, T., Straneo, F., and Bower, A. S.: Seasonal and interannual variability of the West Greenland Current System in the Labrador Sea in 1993-2008, J. Geophys. Res.-Oceans, 120, 1318-1332, https://doi.org/10.1002/2014JC010386, 2015.

Rytter, F., Knudsen, K. L., Seidenkrantz, M.-S., and Eiríksson, J.: Modern distribution of benthic foraminifera on the north Icelandic shelf and slope, J. Foramin. Res., 32, 217-244, https://doi.org/10.2113/32.3.217, 2002.

Saini, J., Stein, R., Fahl, K., Weiser, J., Hebbeln, D., HillaireMarcel, C., and de Vernal, A.: Holocene variability in sea ice and primary productivity in the northeastern Baffin Bay, Arktos, 1-19, https://doi.org/10.1007/s41063-020-00075-y, 2020.

Saito, S.: Major and trace element geochemistry of sediments from East Greenland Continental Rise: an implication for sediment provenance and source area weathering, in: Proc. ODP, Sci. Results, edited by: Saunders, A. D., Larsen, H. C., and Wise Jr., S. W., 152: College Station, TX (Ocean Drilling Program), 19-28, https://doi.org/10.2973/odp.proc.sr.152.207.1998, 1998.

Schröder-Adams, C. J. and Van Rooyen, D.: Response of Recent Benthic Foraminiferal Assemblages to Contrasting Environments in Baffin Bay and the Northern Labrador Sea, Northwest Atlantic, Arctic, 64, 317-341, 2011.

Scott, D. B., Schell, T., Rochon, A., and Blasco, S.: Benthic foraminifera in the surface sediments of the Beaufort Shelf and slope, Beaufort Sea, Canada: Applications and implications for past sea-ice conditions, J. Mar. Syst., 74, 840-863, https://doi.org/10.1016/j.jmarsys.2008.01.008, 2008.

Seidenkrantz, M.-S.: Cassidulina teretis Tappan and Cassidulina neoteretis new species (Foraminifera): stratigraphic markers for deep sea and outer shelf areas, J. Micropalaeontol., 14, 145-157, https://doi.org/10.1144/jm.14.2.145, 1995.

Seidenkrantz, M. S.: Benthic foraminifera as palaeo sea-ice indicators in the subarctic realm - examples from the Labrador Sea-Baffin Bay region, Quaternary Sci. Rev., 79, 135-144, https://doi.org/10.1016/j.quascirev.2013.03.014, 2013.

Seidenkrantz, M. S., Aagaard-Sørensen, S., Sulsbrück, H., Kuijpers, A., Jensen, K. G., and Kunzendorf, H.: Hydrography and climate of the last 4400 years in a SW Greenland fjord: Implications for Labrador Sea palaeoceanography, Holocene, 17, 387401, https://doi.org/10.1177/0959683607075840, 2007.

Seidenkrantz, M. S., Roncaglia, L., Fischel, A., Heilmann-Clausen, C., Kuijpers, A., and Moros, M.: Variable North Atlantic climate seesaw patterns documented by a late Holocene marine record from Disko Bugt, West Greenland, Mar. Micropaleontol., 68, 6683, https://doi.org/10.1016/j.marmicro.2008.01.006, 2008.

Seidenkrantz, M.-S., Ebbesen, H., Aagaard-Sørensen, S., Moros, M., Lloyd, J. M., Olsen, J., Faurschou Knudsen, M., and Kuijpers, A.: Early Holocene large-scale meltwater discharge from Greenland documented by foraminifera and sediment parameters, Palaeogeogr. Palaeocl., 391, 71-81, https://doi.org/10.1016/j.palaeo.2012.04.006, 2013.

Sheldon, C. M., Seidenkrantz, M. S., Pearce, C., Kuijpers, A., Hansen, M. J., and Christensen, E. Z.: Holocene oceanographic changes in SW Labrador Sea, off Newfoundland, Holocene, 26, 274-289, https://doi.org/10.1177/0959683615608690, 2016.

Sicre, M. A., Weckström, K., Seidenkrantz, M. S., Kuijpers, A., Benetti, M., Masse, G., Ezat, U., Schmidt, S., Bouloubassi, I., Olsen, J., Khodri, M., and Mignot, J.: Labrador current variability over the last 2000 years, Earth Planet. Sc. Lett., 400, 26-32, https://doi.org/10.1016/j.epsl.2014.05.016, 2014.

Ślubowska-Woldengen, M., Rasmussen, T. L., Koç, N., KlitgaardKristensen, D., Nilsen, F., and Solheim, A.: Advection of Atlantic Water to the western and northern Svalbard shelf since 17500 cal. yr BP, Quaternary Sci. Rev., 26, 463-478, https://doi.org/10.1016/j.quascirev.2006.09.009, 2007.

Solignac, S., Seidenkrantz, M. S., Jessen, C., Kuijpers, A., Gunvald, A. K., and Olsen, J.: Late-holocene sea-surface conditions offshore Newfoundland based on dinoflagellate cysts, Holocene, 21, 539-552, https://doi.org/10.1177/0959683610385720, 2011.

Steenfelt, A.: Geochemical atlas of Greenland - West and South Greenland, in: Danmarks og Grønlands Geologiske Undersøgelse: Rapport 2001/46, 39 pp., 2001.

Steenfelt, A., Thomassen, B., Lind, M., and Kyed, J.: Karrat 97: reconnaissance mineral exploration in central 761 West Greenland, Geol. Greenl. Surv. Bull., 180, 73-80, 1998.

Straneo, F. and Heimbach, P.: North Atlantic warming and the retreat of Greenland's outlet glaciers, Nature, 504, 36-43, https://doi.org/10.1038/nature12854, 2013.

Straneo, F., Heimbach, P., Sergienko, O., Hamilton, G., Catania, G., Griffies, S., Hallberg, R., Jenkins, A., Joughin, I., Motyka, R., Pfeffer, W. T., Price, S. F., Rignot, E., Scambos, T., Truffer, M., and Vieli, A.: Challenges to understanding the dynamic response of Greenland's marine terminating glaciers to oc eanic and atmospheric forcing, B. Am. Meteorol. Soc., 94, 1131-1144, https://doi.org/10.1175/BAMS-D-12-00100.1, 2013.

Tan, F. C. and Strain, P. M.: The distribution of sea ice melt water in the Eastern Canadian Arctic, J. Geophys. Res., 85, 1925-1932, 1980. 
Tang, C. C. L., Ross, C. K., Yao, T., Petrie, B., DeTracey, B. M., and Dunlap, E.: The circulation, water masses and sea-ice of Baffin Bay, Prog. Oceanogr., 63, 183-228, https://doi.org/10.1016/j.pocean.2004.09.005, 2004.

Thyrring, J., Rysgaard, S., Blicher, M. E., and Sejr, M. K.: Metabolic cold adaptation and aerobic performance of blue mussels (Mytilus edulis) along a temperature gradient into the High Arctic region, Mar. Biol., 162, 235-243, https://doi.org/10.1007/s00227-014-2575-7, 2015.

Tremblay, J.-É., Payne, C. D., Price, N. M., Gratton, Y., and Carmack, E. C.: Impact of the large-scale Arctic circulation and the North Water Polynya on nutrient inventories in Baffin Bay, J. Geophys. Res., 107, 26-1-26-14, https://doi.org/10.1029/2000JC000595, 2002.

Vermassen, F., Andreasen, N., Wangner, D. J., Thibault, N., Seidenkrantz, M.-S., Jackson, R., Schmidt, S., Kjær, K. H., and Andresen, C. S.: A reconstruction of warm-water inflow to Upernavik Isstrøm since $1925 \mathrm{CE}$ and its relation to glacier retreat, Clim. Past, 15, 1171-1186, https://doi.org/10.5194/cp-15-11712019, 2019.

Wang, J., Mysak, L. A., and Grant Ingram, R.: Interannual variability of sea-ice cover in hudson bay, baffin bay and the Labrador sea, Atmos.-Ocean, 32, 421-447, https://doi.org/10.1080/07055900.1994.9649505, 1994.

Wangner, D. J., Jennings, A. E., Vermassen, F., Dyke, L. M., Hogan, K. A., Schmidt, S., Kjær, K. H., Knudsen, M. F., and Andresen, C. S.: A 2000-year record of ocean influence on Jakobshavn Isbræ calving activity, based on marine sediment cores, Holocene, 28, 1731-1744, https://doi.org/10.1177/0959683618788701, 2018.
Weatherall, P., Marks, K. M., Jakobsson, M., Schmitt, T., Tani, S., Arndt, J. E., Rovere, M., Chayes, D., Ferrini, V. and Wigley, R.: A new digital bathymetric model of the world's oceans, Earth Sp. Sci., 2, 331-345, https://doi.org/10.1002/2015EA000107, 2015.

Welford, J. K., Peace, A. L., Geng, M., Dehler, S. A., and Dickie, K.: Crustal structure of Baffin Bay from constrained three-dimensional gravity inversion and deformable plate tectonic models, Geophys. J. Int., 214, 1281-1300, https://doi.org/10.1093/GJI/GGY193, 2018.

Wollenburg, J. E. and Kuhnt, W.: The response of benthic foraminifers to carbon flux and primary production in the Arctic Ocean, Mar. Micropaleontol., 40, 189-231, https://doi.org/10.1016/S0377-8398(00)00039-6, 2000.

Wollenburg, J. E. and Mackensen, A.: Living benthic foraminifers from the central Arctic Ocean: Faunal composition, standing stock and diversity, Mar. Micropaleontol., 34, 153-185, https://doi.org/10.1016/S0377-8398(98)00007-3, 1998.

Yang, Q., Dixon, T. H., Myers, P. G., Bonin, J., Chambers, D., and Van Den Broeke, M. R.: Recent increases in Arctic freshwater flux affects Labrador Sea convection and Atlantic overturning circulation, Nat. Commun., 7, https://doi.org/10.1038/ncomms10525, 2016.

Zreda, M., England, J., Phillips, F., Elmore, D., and Sharma, P.: Unblocking of the Nares Strait by Greenland and Ellesmere ice-sheet retreat 10000 years ago, Nature, 398, 139-142, https://doi.org/10.1038/18197, 1999. 